\title{
Novel Correlations between Spectroscopic and Morphological Properties of Activated Carbons from Waste Coffee Grounds
}

\author{
Egle Rosson ${ }^{1}$, Paolo Sgarbossa ${ }^{1}\left(\mathbb{D}\right.$, Mirto Mozzon ${ }^{1}$, Federico Venturino ${ }^{2}$, Sara Bogialli ${ }^{2}{ }^{\infty}$, Antonella Glisenti ${ }^{2}(\mathbb{D}$, \\ Aldo Talon ${ }^{3}$, Elisa Moretti ${ }^{3}{ }^{6}$, Sara Maria Carturan ${ }^{4}$, Sergio Tamburini ${ }^{5}$, Alessia Famengo ${ }^{5}$, \\ Ana Paula da Costa Ribeiro ${ }^{6}\left(\mathbb{0}\right.$, Sadjia Benhabiles ${ }^{7}$, Rida Kamel ${ }^{7}$, Federico Zorzi ${ }^{8} \mathbb{D}$ and Roberta Bertani ${ }^{1, *} \mathbb{( \mathbb { C }}$
}

check for updates

Citation: Rosson, E.; Sgarbossa, P.; Mozzon, M.; Venturino, F.; Bogialli, S.; Glisenti, A.; Talon, A.; Moretti, E.; Carturan, S.M.; Tamburini, S.; et al. Novel Correlations between Spectroscopic and Morphological Properties of Activated Carbons from Waste Coffee Grounds. Processes 2021 9, 1637. https://doi.org/10.3390/ pr9091637

Academic Editors: David W. Mazyck, Amy Borello Gruss and Emily K. Faulconer

Received: 23 June 2021

Accepted: 8 September 2021

Published: 10 September 2021

Publisher's Note: MDPI stays neutral with regard to jurisdictional claims in published maps and institutional affiliations.

Copyright: (c) 2021 by the authors. Licensee MDPI, Basel, Switzerland. This article is an open access article distributed under the terms and conditions of the Creative Commons Attribution (CC BY) license (https:// creativecommons.org/licenses/by/ $4.0 /)$.
1 Dipartimento di Ingegneria Industriale, Università degli Studi di Padova, via F. Marzolo 9, 35131 Padova, Italy; egle.rosson@gmail.com (E.R.); paolo.sgarbossa@unipd.it (P.S.); mirto.mozzon@unipd.it (M.M.)

2 Dipartimento di Scienze Chimiche, Università degli Studi di Padova, via F. Marzolo 1, 35131 Padova, Italy; federico.venturino@pec.chimicifisici.it (F.V.); sara.bogialli@unipd.it (S.B.); antonella.glisenti@unipd.it (A.G.)

3 Dipartimento di Scienze Molecolari e Nanosistemi, Università Ca' Foscari Venezia, via Torino 155 , 30172 Venezia Mestre, Italy; aldair@unive.it (A.T.); elisam@unive.it (E.M.)

4 Dipartimento di Fisica e Astronomia, Università degli Studi di Padova, Laboratori INFN, viale dell'Università 2, 35020 Legnaro, Italy; saramaria.carturan@unipd.it

5 Consiglio Nazionale delle Ricerche, Istituto di Chimica della Materia Condensata e di Tecnologie per l'Energia, Corso Stati Uniti 4, 35127 Padova, Italy; sergio.tamburini@cnr.it (S.T.); alessia.famengo@cnr.it (A.F.)

6 Centro de Química Estrutural, Instituto Superior Técnico, Lisbona, Avenida Rovisco Pais 1, 1049-001 Lisbon, Portugal; apribeiro@tecnico.ulisboa.pt

7 Laboratoire d'Etude sur les Interactions Matériaux-Environnement, Faculté des Science et de la Technologie, Université Mohamed Seddik BenYahia, BP 98 Ouled Aissa, Jijel 18000, Algeria; benhabiles_sadjia@yahoo.fr (S.B.); rida_kamel2001@yahoo.fr (R.K.)

8 Centro di Analisi e Servizi per la Certificazione, Università degli Studi di Padova, via Jappelli 1, 35131 Padova, Italy; federico.zorzi@unipd.it

* Correspondence: roberta.bertani@unipd.it

Abstract: Massive quantities of spent coffee grounds (SCGs) are generated by users around the world. Different processes have been proposed for SCG valorization, including pyrolytic processes to achieve carbonaceous materials. Here, we report the preparation of activated carbons through pyrolytic processes carried out under different experimental conditions and in the presence of various porosity activators. Textural and chemical characterization of the obtained carbons have been achieved through Brunauer-Emmett-Teller (BET), ESEM, ${ }^{13} \mathrm{C}$ solid state NMR, XPS, XRD, thermogravimetric and spectroscopic determinations. The aim of the paper is to relate these data to the preparation method, evaluating the correlation between the spectroscopic data and the physical and textural properties, also in comparison with the corresponding data obtained for three commercial activated carbons used in industrial adsorption processes. Some correlations have been observed between the Raman and XPS data.

Keywords: spent coffee grounds; activated carbon; pyrolysis; Raman and XPS and XRD spectroscopies; chemical and morphological characterization

\section{Introduction}

Coffee is the second most popular beverage after water and the second largest traded commodity after petroleum, thus massive quantities of waste are generated by industries and users around the world, which represent an abundant and low-cost bio-resource for energy and chemicals due to their high organic content, opening up a wide range of applications in a circular economy perspective [1-7]. With an estimated average of $11 \mathrm{~g}$ of fresh ground coffee going into each cup, around 6 million tons of wet waste of ground coffee are brewed every year around the world (it was evaluated that 1 ton of green coffee generates about $650 \mathrm{~kg}$ of spent coffee grounds (SCGs) and about $2 \mathrm{~kg}$ of wet SCGs from 
$1 \mathrm{~kg}$ of soluble coffee) [8,9]. Different processes have been proposed in the literature for the valorization of spent coffee grounds (Scheme 1), which can be summarized into the following five principal topics [10]:

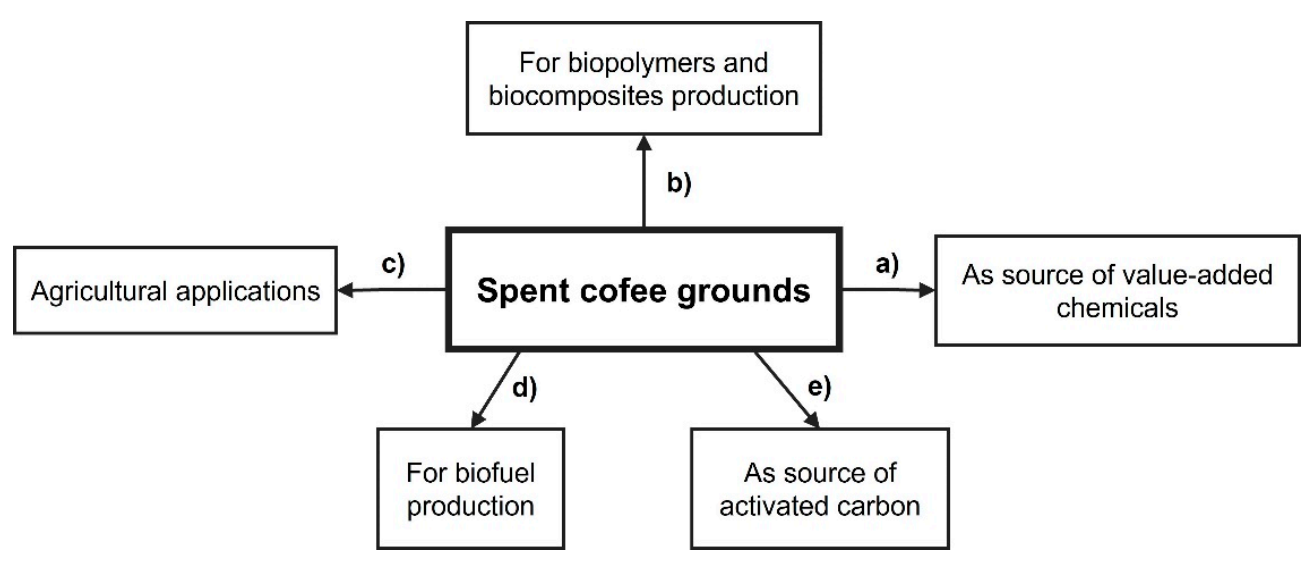

Scheme 1. Topics for the valorization of spent coffee ground.

(a) Value-added chemicals can be recovered by extraction or by enzymatic processes to achieve [3,11]: polysaccharides (about $45 \% w / w$, of dry weight of the material, mainly consisting of mannan, galactomannan, arabinogalactane and cellulose [12]); proteins (about $13 \% w / w$, with a low content of aromatic amino acids and high content of leucine); caffeine (about $1.8 \mathrm{mg} / \mathrm{g}$ ); brown-colored compounds (melanoidins); lipids (10-20\% w/w, with characteristics similar to petroleum ether extracts: diterpene alcohol esters about $12 \%$, sterols approximately $2 \%$, and approximately $2 \%$ of polar materials and sterol esters together with triacyglycerols in about $85 \%$ amount mainly of linoleic, palmitic, stearic, oleic and linolenic acids); minerals (ranging from 1 to $3 \% w / w$, consisting in 3-21 mg/g of $\mathrm{K}, \mathrm{Mg}$ from 0.1 to $0.4 \mathrm{mg} / \mathrm{g}$ together with traces of $\mathrm{P}, \mathrm{Co}, \mathrm{Na}, \mathrm{Fe}, \mathrm{Mn}$, and $\mathrm{Cu}$ ) and phenolic compound as antioxidants (about $20 \% w / w$, mainly chlorogenic acid and its derivatives) $[4,13]$.

(b) Biopolymers and biocomposites can be achieved owing to the high content of hemicellulose, cellulose, and lignin, thus SCGs have been proposed as reinforcement agents for polymers $[14,15]$ or mixed with natural waxes to prepare biobased polymeric composite material (PCM) [16] or in suspension with silicone oil to achieve electrorheological fluids [17].

(c) The positive impact as soil amendment of SCGs has been shown in lettuce physical and nutritional features [18] or in improving microbial activity and reducing leaching of mineral nitrogen from the arable soil [19]. SCGs have been also studied as additive in animal feed [20] and in integrated hydrothermal carbonization-anaerobic digestion processes to improve biomethane production.

(d) Many papers explored the availability of SCGs for energy recovery [21]: from biodiesel [22], hydrocarbons [23], to bioethanol and bioether [24,25], bio-oil [26,27], or biogas [28] preparation.

(e) The preparation of activated carbon was extensively studied starting from SCGs with different purposes: as adsorbent material for water purification [29-34] and in particular for heavy metal removal from water [35] or amelioration of environmental pollution [36]; as media for separation of hydrogen sulfide from air at ambient conditions [37]; for $\mathrm{CO}_{2}$ capture [38-41] and as materials for methane [42], hydrogen [43], or lithium [44] storage. Activated carbon from wastes was also studied as a catalyst [45] or a support for metal catalysts [46]. Recently, intriguing papers have been reported concerning the influence of the preparation processes on the activated carbon derived from SCGs as anodic or cathodic material in carbon or microbial fuel cells, respectively [47], in sodium ion [48] or Li-Se batteries [49]. High-capacitance nitrogen-containing nano-porous carbon materials from 
SCGs have been shown to exhibit high performance as supercapacitor electrodes for energy storage applications $[40,41,50]$.

Technological applications of activated carbons (ACs) in adsorption processes are becoming increasingly broader in different sectors including pharmaceutical uses [51]. In this last frame, ACs are applied either in industry for the purification of pharmaceutical products to remove unwanted impurities and as a nutraceutical or active pharmaceutical ingredient. Furthermore, ACs have an undisputed role in the treatment of acutely poisoned patients, being considered the universal antidote. Some stringent characteristics are necessary for use of ACs in this context; a high degree of microporosity with surface area values towards $2000 \mathrm{~m}^{2} / \mathrm{g}$ or higher, and traceability of the starting materials and synthetic process (no animal contact).

The preparation of ACs consists of two main steps: carbonization of a carbonaceous raw material typically via pyrolysis in an inert atmosphere (to achieve pyrochar, a carbon rich and thermally stable product) followed by chemical or physical activation to develop porosity. As for raw materials, in recent years, increasing attention has been devoted to renewable resources and biomasses, including wastes, being inexpensive and largely available. The use of waste coffee grounds as a source of ACs is particularly intriguing because of the possibility to agree with the qualification for pharmaceutical applications, with the raw material belonging to the food chain. Different synthetic protocols have been reported to influence strongly the morphological, physical, and chemical properties of the activated carbon obtained.

As for physical activation processes, treatment with gases such as $\mathrm{CO}_{2}$ [52-54] or steam [55] have been performed, while as chemical activators dehydrating agents and oxidants such as $\mathrm{H}_{3} \mathrm{PO}_{4}, \mathrm{H}_{2} \mathrm{SO}_{4}$ or bases such as $\mathrm{NaOH}$ or $\mathrm{KOH}$ have been considered besides $\mathrm{ZnCl}_{2}$ [56]. Even if physical activation is largely employed for large amounts of AC preparation for industrial and environmental applications, chemical activation is exploited due to the modulation of chemical and physical properties of the final AC, depending on the experimental parameters, such as time, temperature, activating agent/precursor ratio and activator nature. The $\mathrm{KOH}$ activation of waste coffee grounds was proposed to involve the generation of pore structures via redox reactions between potassium compounds and carbon, followed by the additional development of pore structures via the gasification of carbon and the expanding of carbon lattices by intercalating metallic $\mathrm{K}$ generated during activation into the carbon matrix [57]. Also, water vapor and carbon material undergo a steam reforming reaction yielding the porous structure [1].

Even if many studies have been reported concerning the valorization of coffee grounds into ACs, some experimental and characterization aspects deserve, to the best of our knowledge, further consideration [1]. The aim of the present work was to prepare ACs from two different waste coffee grounds, under different experimental conditions and to achieve to a more detailed characterization with the aim to correlate their spectroscopic data with physical and textural properties, also in comparison with the corresponding data obtained for three commercial activated carbons used in industrial adsorption processes.

\section{Materials and Methods}

\subsection{Raw Materials}

Two different types of waste coffee ground were collected from local cafeterias: samples R (Robusta, dark brown flakes, scraggy with deep pores; Figure S1a) and A (Arabica, light brown, more compact, flakes, Figure S1b). They were dried at $110^{\circ} \mathrm{C}$ for $24 \mathrm{~h}$ and kept under vacuum to avoid the formation of mold. A preliminary elemental analysis (averaged values of five samples) gave the results reported in Table 1. It is notable that there is a good agreement with the X-ray fluorescence (XRF, Figure S1) and literature data [58] showing that sample A had a better energy value compared with $\mathrm{R}$, having higher " $\mathrm{H}: \mathrm{C}$ " ratio and lower "O:C" ratio, as suggested for the correlation of higher hydrogen and carbon content to the heating value of biomass material [59]. 
Table 1. Elemental analysis $(\% w / w)$ of the waste coffee grounds starting materials ${ }^{1}$.

\begin{tabular}{ccccccc}
\hline Sample & $\mathbf{C}$ & $\mathbf{H}$ & $\mathbf{N}$ & $\mathbf{S}$ & "H:C" Ratio & "O:C" Ratio \\
\hline Robusta (R) & 52.5 & 6.9 & 2.2 & $<0.05$ & 0.13 & 0.89 \\
Arabica (A) & 56.0 & 7.9 & 2.5 & $<0.05$ & 0.14 & 0.78 \\
\hline
\end{tabular}

${ }^{1}$ The data correspond to averaged values of at least three measurements performed on five independent samples.

Then the samples were washed with water, ethanol, or hexane to remove impurities and organic compounds. The ethanol and hexane solutions were analyzed by gas chromatography-mass spectrometry (GCMS): they showed the presence of caffeine and methyl- and ethyl-ester-derivatives of palmitic and stearic acids, in a larger extent in the ethanol extract. (Figure S2).

\subsection{Preparation of Activated Carbons}

The washed powders (typically $10 \mathrm{~g}$ ) were pyrolyzed under nitrogen (flow rate 100 or $150 \mathrm{~mL} / \mathrm{min}$ ) from room temperature to the final one (heating rate $20^{\circ} \mathrm{C} / \mathrm{min}$ ) for $2 \mathrm{~h}$ in a horizontal stainless-steel reactor in the presence of activator agents as scheduled in Table 2. After cooling, the resulting RACs (Robusta Activated Carbons, from Robusta) and AACs (Arabica Activated Carbons, from Arabica) samples were washed with a $0.1 \mathrm{M} \mathrm{HCl}$ solution, followed by hot distilled water until neutrality. The ACs were collected, dried at $110{ }^{\circ} \mathrm{C}$ for $24 \mathrm{~h}$ and kept in tightly closed bottles for further analyses. All the data were compared with those of three commercial activated carbons used in industrial adsorption processes (Samples M, C, and LP39).

Table 2. Experimental conditions for preparation of activated carbons (ACs) and labeling.

\begin{tabular}{|c|c|c|c|c|c|}
\hline Sample & $\begin{array}{l}\text { Preliminary } \\
\text { Washing }\end{array}$ & $\begin{array}{c}\text { Activating Agent } \\
\text { (Activator/Substrate Ratio } w / w \text { ) }\end{array}$ & $\begin{array}{c}\text { Pyrolysis } \\
\text { Temperature } \\
\left({ }^{\circ} \mathrm{C}\right)\end{array}$ & $\begin{array}{l}\text { Yield } \\
(\%)\end{array}$ & $\begin{array}{l}\text { Surface Area } \\
\left(\mathrm{m}^{2} / \mathrm{g}\right)\end{array}$ \\
\hline RAC-1 $^{1}$ & $\begin{array}{l}\text { EtOH, } 24 \text { h RT + } \\
\text { Hexane } 24 \text { h RT }\end{array}$ & $\mathrm{KOH}(1: 1)$ & 800 & 15 & 629 \\
\hline $\mathrm{RAC}^{-1} \mathbf{2}^{1}$ & $\begin{array}{l}\text { EtOH, } 24 \text { h RT + } \\
\text { Hexane } 24 \text { h RT }\end{array}$ & $\mathrm{K}_{2} \mathrm{CO}_{3}(1: 1)$ & 600 & 13 & 765 \\
\hline $\mathrm{RAC}^{-3^{1}}$ & $\mathrm{H}_{2} \mathrm{O}$ & none & 800 & 10 & 478 \\
\hline${\text { RAC }-4^{1}}^{1}$ & $\mathrm{H}_{2} \mathrm{O}$ & $\mathrm{ZnCl}_{2}(1: 1)$ & 800 & 15 & 367 \\
\hline AAC-1 & $\mathrm{H}_{2} \mathrm{O}$ & $\mathrm{KOH}(1: 1)$ & 800 & 12 & 1407 \\
\hline AAC-2 & $\begin{array}{l}\mathrm{H}_{2} \mathrm{O}, 24 \mathrm{~h} \mathrm{RT}+ \\
\text { Hexane } 24 \text { h RT }\end{array}$ & $\mathrm{KOH}(1: 1)$ & 800 & 12 & 1362 \\
\hline $\mathrm{AAC}-3^{2}$ & $\mathrm{EtOH}, 1 \mathrm{~h} \mathrm{RT}$ & $\begin{array}{c}\mathrm{NaHCO}_{3} / \mathrm{CH}_{3} \mathrm{COOH}(1: 1: 1) \text { under stirring } \\
\text { one night, RT; + KOH (1:1) }\end{array}$ & 800 & 12 & 1868 \\
\hline $\mathrm{AAC}-4^{2}$ & $\mathrm{H}_{2} \mathrm{O}, 24 \mathrm{~h} \mathrm{RT}$ & $\mathrm{KOH}(1: 1)$ & 800 & 10 & 1535 \\
\hline AAC-5 & $\begin{array}{l}\text { EtOH, } 24 \text { h RT + } \\
\text { Hexane } 24 \text { h RT }\end{array}$ & $\mathrm{KOH}(1: 1)$ & 600 & 15 & 615 \\
\hline AAC-6 & $\begin{array}{l}\text { EtOH, } 24 \text { h RT + } \\
\text { Hexane } 24 \text { h RT }\end{array}$ & $\mathrm{KOH}(1: 1)$ & 700 & 13 & 1715 \\
\hline AAC-7 & $\begin{array}{l}\text { EtOH, } 24 \text { h RT + } \\
\text { Hexane } 24 \text { h RT }\end{array}$ & $\mathrm{KOH}(1: 1)$ & 800 & 12 & 1375 \\
\hline $\mathrm{AAC}-8^{3}$ & $\begin{array}{l}\text { EtOH, } 24 \text { h RT + } \\
\text { Hexane } 24 \text { h RT }\end{array}$ & $\mathrm{KOH}(1: 1)$ & 700 & 12 & 721 \\
\hline $\mathrm{AAC}_{-9}{ }^{4}$ & none & $\mathrm{KOH}(1: 1)$ & 800 & 30 & 1200 \\
\hline AAC $-10^{5}$ & $\begin{array}{l}\text { EtOH, } 24 \text { h RT + } \\
\text { Hexane } 24 \text { h RT }\end{array}$ & $\mathrm{KOH}(1: 1)$ & 600 & 17 & 495 \\
\hline
\end{tabular}


Table 2. Cont.

\begin{tabular}{|c|c|c|c|c|}
\hline Sample & $\begin{array}{c}\text { Activating Agent } \\
\text { (Activator/Substrate Ratio } w / w \text { ) }\end{array}$ & $\begin{array}{c}\text { Pyrolysis } \\
\text { Temperature } \\
\left({ }^{\circ} \mathrm{C}\right)\end{array}$ & $\begin{array}{l}\text { Yield } \\
(\%)\end{array}$ & $\begin{array}{l}\text { Surface Area } \\
\left(\mathrm{m}^{2} / \mathrm{g}\right)\end{array}$ \\
\hline $\mathbf{M}$ & $\begin{array}{l}\text { Commercial: Merck, K39413913 002; } \\
\text { activated charcoal, extra food pure grade }\end{array}$ & unknown & & 823 \\
\hline $\mathrm{C}$ & Commercial: CECA, Arkema, Acticarbone NCL 1240 & unknown & & 932 \\
\hline LP39 & Commercial: Jacobi ${ }^{\circledR}$ LP39 ${ }^{\circledR}$ & unknown & & 1782 \\
\hline
\end{tabular}

${ }^{1} \mathrm{~N}_{2}$ flow rate $150 \mathrm{~mL} / \mathrm{min}^{2}$ During the pyrolysis $\mathrm{CH}_{4}$ was formed; ${ }^{3}$ After preliminary washing, the powder was heated at $500{ }^{\circ} \mathrm{C}$ for $1 \mathrm{~h}$ before pyrolysis; ${ }^{4}$ The pyrolysis was carried out on a larger mass (c.a. $100 \mathrm{~g}$ ); ${ }^{5}$ The pyrolysis was carried out in a vertical glass reactor.

\subsection{Textural and Chemical Characterization}

The textural properties of the samples were studied by $\mathrm{N}_{2}$ adsorption at $77 \mathrm{~K}$ with a static volumetric instrument (ASAP2020 or ASAP2010, Micrometrics) over a wide relative pressure range from about $10^{-6}$ to $0.998\left(\mathrm{p} / \mathrm{p}_{0}\right)$. Prior to the analysis, all the samples were degassed at $353 \mathrm{~K}$ for $18 \mathrm{~h}$ under vacuum to completely remove any trace of adsorbed water. The specific surface area of the samples was assessed by the standard Brunauer-EmmettTeller (BET) method (software available in the instruments), using $\mathrm{N}_{2}$ adsorption data in the relative pressure ranging from 0.001 to 0.35 , and by applying the Density Functional Theory (DFT) Plus Software provided by Micrometrics. The total pore volume was estimated from the amount of nitrogen adsorbed at a relative pressure of about 0.98 . Pore size distributions (PSDs) were calculated by using the Barret-Joyner-Halenda algorithm for mesopores (2-50 nm) using the desorption branch.

Magic angle spinning-solid state nuclear magnetic resonance (MAS-NMR) experiments were collected on a Bruker AVANCE III spectrometer 300 (magnetic field of 7.0 T corresponding to ${ }^{13} \mathrm{C}$ Larmor frequencies of $75.468 \mathrm{MHz}$ ) equipped for solid-state analysis with $4 \mathrm{~mm}$ diameter zirconia rotors and $\mathrm{K}_{\mathrm{el}}-\mathrm{F}$ caps. The magic angle (MA) was accurately adjusted prior to data acquisition using $\mathrm{KBr} .{ }^{13} \mathrm{C}$ chemical shifts were externally referenced to solid adamantane at $38.48 \mathrm{ppm}$ (in relation to tetramehtylsilane, TMS). Both ${ }^{13} \mathrm{C}$ MAS and ${ }^{13} \mathrm{C}$ cross-polarization (CP-MAS) spectra were collected. For CP-MAS, the solid-state ${ }^{13} \mathrm{C}\left\{{ }^{1} \mathrm{H}\right\}$ nuclear magnetic resonance spectra were recorded using the combination of cross-polarization, proton decoupling and magic angle spinning. Rotation at the magic angle at a frequency of $8 / 10 \mathrm{KHz}$ was used in ${ }^{13} \mathrm{C} \mathrm{CP}-\mathrm{MAS}$ measurements (see supplementary); duration of proton $\pi / 2$ pulses $4 \mu \mathrm{s},{ }^{1} \mathrm{H}-{ }^{13} \mathrm{C}$ contact time $2 \mathrm{~ms}$, interval between pulses D1 (see supplementary). ${ }^{13} \mathrm{C}-{ }^{1} \mathrm{H}$ dipolar interactions were suppressed via proton decoupling with the corresponding proton resonance frequency $(300.13 \mathrm{MHz})$. Rotation at MA of $10 / 12 \mathrm{kHz}$ was used for ${ }^{13} \mathrm{C}$ MAS (see supplementary) with an interval between ${ }^{13} \mathrm{C}$ pulses of $15 \mathrm{~s}$.

Thermogravimetric analysis (TGA) and differential thermal analysis (DTA) of the samples were conducted with an SDT Q600 TA instrument under air, from $30^{\circ} \mathrm{C}$ up to $1000{ }^{\circ} \mathrm{C}$ at a heating rate of $10^{\circ} \mathrm{C} / \mathrm{min}$ or with a Netzsch STA $449 \mathrm{~F} 1$ Jupiter Thermal Analyzer on $\mathrm{Al}_{2} \mathrm{O}_{3}$ crucibles, heating from $25^{\circ} \mathrm{C}$ to $1000{ }^{\circ} \mathrm{C}$ at $10{ }^{\circ} \mathrm{C} / \mathrm{min}$ under $\mathrm{N}_{2}$ atmosphere $(100 \mathrm{~mL} / \mathrm{min})$. Data were processed via Netzsch Proteus Thermal Analysis software.

X-ray diffraction (XRD) spectra were recorded to characterize samples using a PANalytical X'Pert Pro diffractometer equipped with a Co X-ray tube and a real-time multiple strip (RTMS) detector ( $X^{\prime}$ Celerator).

X-ray photoelectron spectroscopy (XPS) was carried out by means of a Perkin Elmer PHI 5600ci Multi Technique System, using AlK $\alpha$ radiation $(1486.6 \mathrm{eV})$ working at $250 \mathrm{~W}$. The spectrometer was calibrated by assuming the binding energy (BE) of the $4 f_{7 / 2}$ line to be $84.0 \mathrm{eV}$ with respect to the Fermi level. Both extended and detailed spectra were collected. The standard deviation in the BE value of the XPS line is $0.1 \mathrm{eV}$. the atomic percentage, after a Shirley-type background subtraction was evaluated by using the PHI sensitivity factors. The peak positions (referred to NIST database) were corrected for the charging effects by considering the $\mathrm{C} 1$ s peak at $285.0 \mathrm{eV}$ and evaluating the $\mathrm{BE}$ differences. 
Fourier transform infrared spectroscopy (FTIR) spectra of coffee and carbon powders were obtained on a Nicolet spectrophotometer Avatar 320 as KBr pellets. For each sample 32 scans were recorded in the range $4000-400 \mathrm{~cm}^{-1}$ in the transmittance mode with a resolution of $4 \mathrm{~cm}^{-1}$.

Raman spectra were recorded using a continuous wave linearly polarized $(514.5 \mathrm{~nm}$ wavelength, $2.41 \mathrm{eV}, 16 \mathrm{~mW}$ power. The laser beam was focused by a $100 \times$ objective lens, resulting in a spot of about $1 \mu \mathrm{m}$ in diameter.

The morphology of the samples was studied by environmental scanning electron microscopy (ESEM, Quanta $200 \mathrm{FEI}$ ) and a semi-quantitative composition was achieved by the XRF embedded. Selected samples were investigated also by transmission electron microscopy (TEM) using a TECNAI FEI G2 microscope by dispersing the powdered AC in deionized water and depositing a drop of the suspension on a carbon-coated copper grid. The PACs (powdered activated carbon) skeletal density was measured by a helium pycnometer (Multivolume Pycnometer 1305 by Micromeritics), obtaining the values reported in Table 3.

Table 3. Density and point of zero charge (PZC) values of some ACs samples.

\begin{tabular}{ccc}
\hline Sample & Density $\left(\mathbf{g} / \mathrm{cm}^{3}\right)$ & PZC \\
\hline AAC-9 & 1.78 & 9.5 \\
M & 1.81 & 8.8 \\
C & 1.96 & 10.5 \\
LP39 & 1.44 & 6.7 \\
\hline
\end{tabular}

The surfaces of some AC samples were chemically characterized by Boehm titration carried out according to the procedure reported in the literature [60]. $0.25 \mathrm{~g}$ of activated carbon were mixed with $25 \mathrm{ml}$ of different solutions: $0.1 \mathrm{M} \mathrm{HCl}, 0.1 \mathrm{M} \mathrm{NaOH}, 0.1 \mathrm{M}$ $\mathrm{NaHCO}_{3}$, and $0.05 \mathrm{M} \mathrm{Na}_{2} \mathrm{CO}_{3}$. The solutions were kept under magnetic stirring (800 rpm) for $24 \mathrm{~h}$, at ambient temperature $\left(20 \pm 2{ }^{\circ} \mathrm{C}\right)$. The activated carbon was removed by filtration and $10 \mathrm{ml}$ of the filtered solutions were titrated with $0.1 \mathrm{M} \mathrm{NaOH}$ solution (for $\mathrm{HCl}$ ) or $0.1 \mathrm{M} \mathrm{HCl}$ solution (for $\mathrm{NaOH}, \mathrm{NaHCO}_{3}$, and $\mathrm{Na}_{2} \mathrm{CO}_{3}$ ), using the Tashiro indicator. The number of acidic sites was determined under the following assumptions: $\mathrm{NaOH}$ neutralizes carboxyl, phenolic, and lactonic groups; $\mathrm{Na}_{2} \mathrm{CO}_{3}$ neutralizes carboxyl and lactonic groups and $\mathrm{NaHCO}_{3}$ neutralizes only carboxyl groups. The number of basic sites was calculated from the titration of $\mathrm{HCl}$ solution with $\mathrm{NaOH}$.

The point of zero charge (PZC) of some activated carbons was determined using the solid addition method according to the literature [61]. Different flasks were prepared with $50 \mathrm{ml}$ of $0.1 \mathrm{M} \mathrm{KNO}_{3}$ solution and $0.1 \mathrm{M} \mathrm{HCl}$ or $0.1 \mathrm{M} \mathrm{NaOH}$ solutions, added dropwise to reach $\mathrm{pH} 2,4,6,8,10$, and 12 . The $\mathrm{pH}$ value was recorded for each flask $\left(\mathrm{pH}_{0}\right)$. We added $1 \mathrm{~g}$ of activated carbon to each flask and the solutions were mixed under magnetic stirring $(800 \mathrm{rpm})$ for $48 \mathrm{~h}$ at ambient temperature $\left(20 \pm 2{ }^{\circ} \mathrm{C}\right)$. The activated carbon was removed by filtration and the $\mathrm{pH}$ of the filtered liquid solution recorded $\left(\mathrm{pH}_{\mathrm{f}}\right)$ for each sample. The difference between the final and the initial $\mathrm{pH}\left(\Delta \mathrm{pH}=\mathrm{pH}_{\mathrm{f}}-\mathrm{pH}_{0}\right)$ was plotted against $\mathrm{pH}_{0}$. The PZC corresponded to $\Delta \mathrm{pH}=0$, which is the intersection of the resulting curve with the $x$ axis (Table 3 ).

\section{Results and Discussion}

\subsection{Characterization of the Starting Spent Coffee Grounds}

In Figure 1 the ${ }^{13} \mathrm{C}-\mathrm{MAS}$ NMR of the washed raw material SCG Arabica has been reported indicating the presence of different compounds in agreement with the literature data [54,62]: saturated and unsaturated chains (signals in the ranges 14-35, 60-80 ppm, $130 \mathrm{ppm}$, and 160-180 ppm due to hydrocarbons and fatty acids) together with carbohydrates, sugar moieties present in chlorogenic acid (CLA) and its derivatives (signals in the $60-100$ ppm range), and signals attributable to caffeine (CF) $\left({ }^{13} \mathrm{C}-\mathrm{CP}\right.$ MAS of caffeine is 
reported in Figure S3) $[11,63]$. The solid state ${ }^{13} \mathrm{C}$ NMR of sample $\mathrm{R}$ is reported in Figure S3 $\left({ }^{13} \mathrm{C}\right.$ MAS NMR chemical shifts are collected in Table S1).

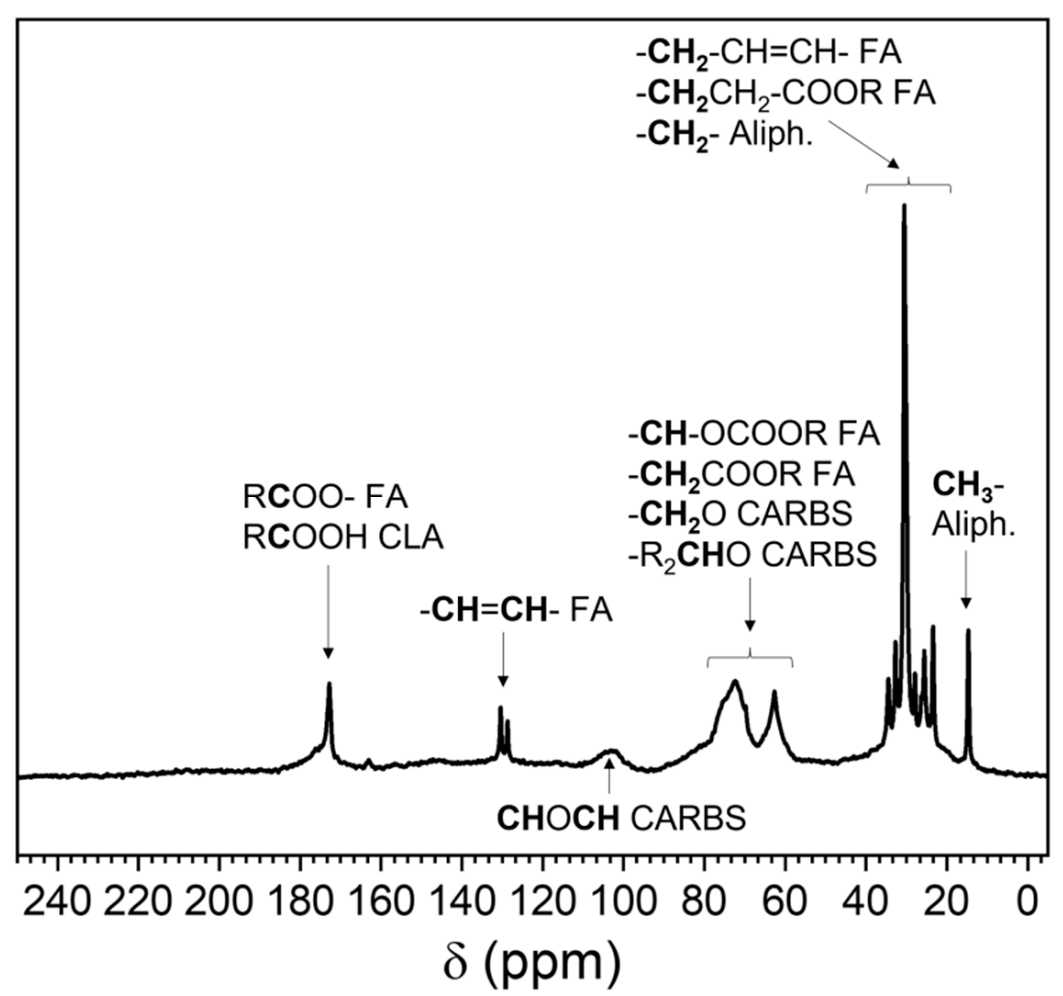

Figure $1 .{ }^{13} \mathrm{C}$ nuclear magnetic resonance (NMR) spectrum in the solid state of the starting spent coffee ground (SCG) Arabica (sample A) (FA = fatty acids, CLA = chlorogenic acid, CARBS = carbohydrates, and Aliph. = aliphatic).

The FTIR spectra of raw sample A has been reported in Figure 2. In the region $3600-3200 \mathrm{~cm}^{-1}$ broad absorptions of $-\mathrm{OH}$ and $-\mathrm{NH}$ functional groups of carboxylic acids and amine groups in caffeine and proteins could be observed. The strong absorptions at 2924 and $2854 \mathrm{~cm}^{-1}$ were due to asymmetric and symmetric stretching of C-H bond in aliphatic chains of caffeine, lipids and hydrocarbons, and the band at $1440 \mathrm{~cm}^{-1}$ was due to the bending of the same moieties. The sharp band at $1743 \mathrm{~cm}^{-1}$ was attributed to the $\mathrm{C}=\mathrm{O}$ absorption in aliphatic esters or triglycerides, while the band at $1660 \mathrm{~cm}^{-1}$ could be assigned to $\mathrm{C}=\mathrm{C}$ vibration of lipids and fatty acids, and to carbonyl stretching of lignin. The band at $1523 \mathrm{~cm}^{-1}$ could be ascribed to $C=C$ vibration of lignin. The bands at 1058 , $1113,1167,1244$ and $1376 \mathrm{~cm}^{-1}$ could be attributed to chlorogenic acids which include esters formed by quinic acid and some trans-cinnamic acids. Axial C-O deformation of the chlorogenic, caffeic and coumarinic acids occurred in the range $1085-1050 \mathrm{~cm}^{-1}$. The absorptions at 1446,1378 , and $897 \mathrm{~cm}^{-1}$ could be attributed to $\beta$-linkage in cellulose [54,62] The similarity of the spectra of the raw R and A materials, in particular the absence of the signals in the range $1724-1705 \mathrm{~cm}^{-1}$ of aliphatic or aromatic acids and ketones indicated that both SCGs derived from coffee roasted in similar thermal conditions [64]. 


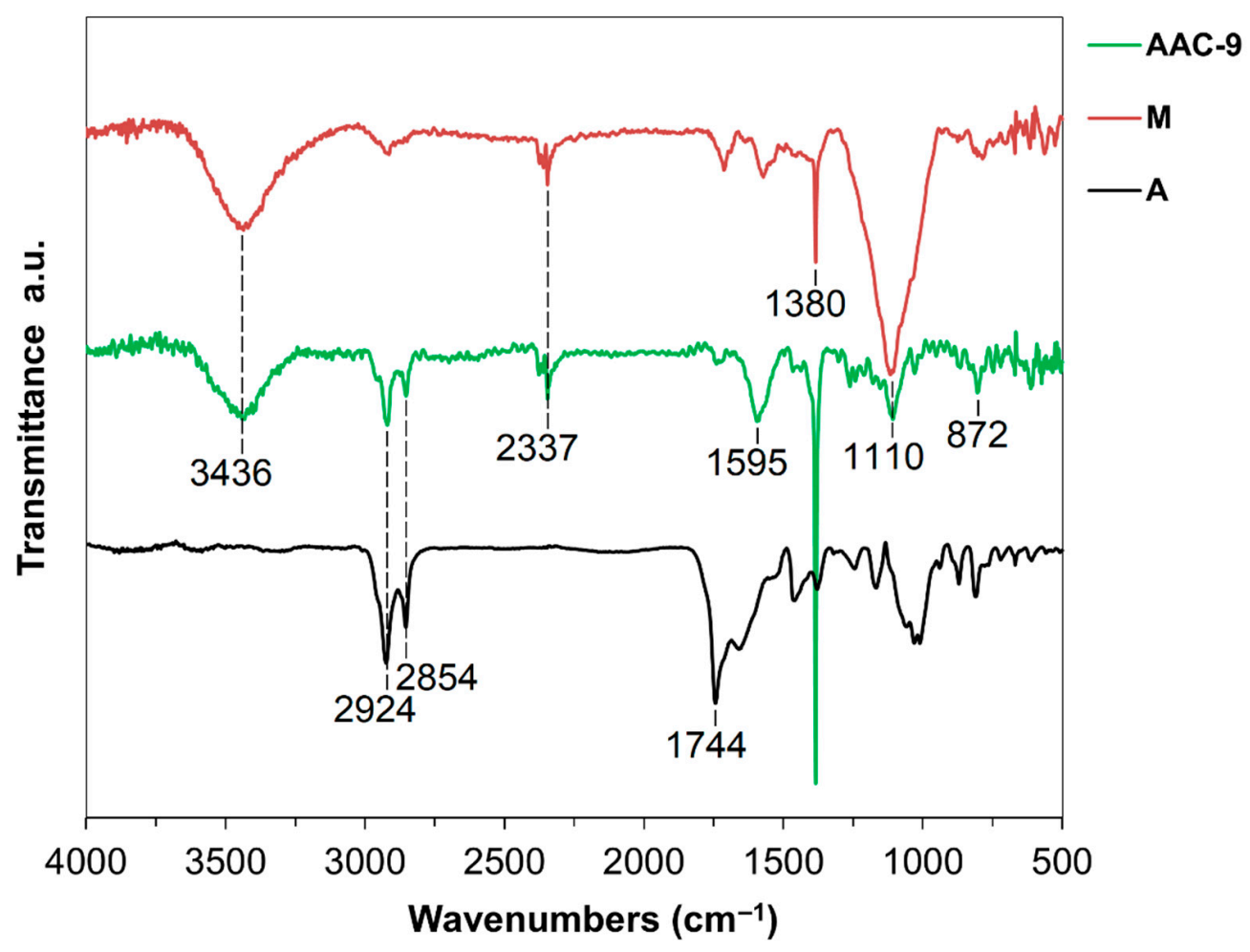

Figure 2. Fourier transform infrared (FTIR) spectra of the starting SCG (sample A), of the derived activated carbon (sample AAC-9), and of the commercial activated carbon (sample $\mathrm{M}$ ) in the range $4000-500 \mathrm{~cm}^{-1}$.

\subsection{Thermal Behavior of Raw Materials $A$ and $R$ and of the $A, R / K O H ~ 1 / 1$ Mixtures}

In Figure S4a,b the combined TG and derivative (DTG) profiles of samples $\mathrm{R}$ and $\mathrm{A}$ in the range $30-920^{\circ} \mathrm{C}$ under air, and in Figure $3 \mathrm{a}, \mathrm{b}$, under nitrogen, have been reported, showing the thermal degradation characteristics of the samples at a heating rate of $10^{\circ} \mathrm{C} / \mathrm{min}$. Under nitrogen a loss of residual moisture of about $5 \%$ was observed (at $95{ }^{\circ} \mathrm{C}$ for $\mathrm{R}$ and $108{ }^{\circ} \mathrm{C}$ for $\mathrm{A}$ ). In the range from 200 to $400{ }^{\circ} \mathrm{C}$, numerous weight losses (approximately $70 \% w / w$ for both $\mathrm{A}$ and $\mathrm{R}$ ) originated by the primary pyrolysis of the SCGs and the formation of a carbonaceous material, with $\mathrm{CO}$ and $\mathrm{CO}_{2}$ evolution and various dehydration reactions of the original biopolymers and/or dehydration of the pyrolysis vapors from removal of - $\mathrm{OH}$ groups were observed. The three peaks indicative of the decomposition of hemicellulose (about $300{ }^{\circ} \mathrm{C}$ ), cellulose (about $330^{\circ} \mathrm{C}$ ) and lignin (about $384^{\circ} \mathrm{C}$ ) were evident in the profile of both samples. The removal of $-\mathrm{OCH}_{3}$ groups from the lignocellulosic structure was associated with the production of $\mathrm{CH}_{4}$ during pyrolysis: the evolution of $\mathrm{H}_{2}, \mathrm{CH}_{4}, \mathrm{C}_{2} \mathrm{H}_{4}$, and $\mathrm{C}_{2} \mathrm{H}_{6}$ has been reported to start from about $250{ }^{\circ} \mathrm{C}$ and continue during complete degradation of the matrix. The burnout was about $450{ }^{\circ} \mathrm{C}$ for both samples with the formation of a solid residue of about 23\% w/w (TG and DTG data of samples A, R, A/KOH, and $\mathrm{R} / \mathrm{KOH}$ are available in Table S2) $[52,59,62,65-67]$. 
(a)

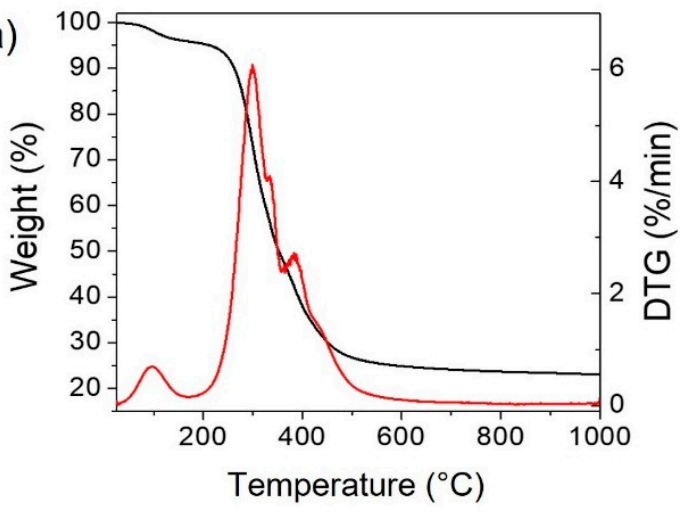

(c)

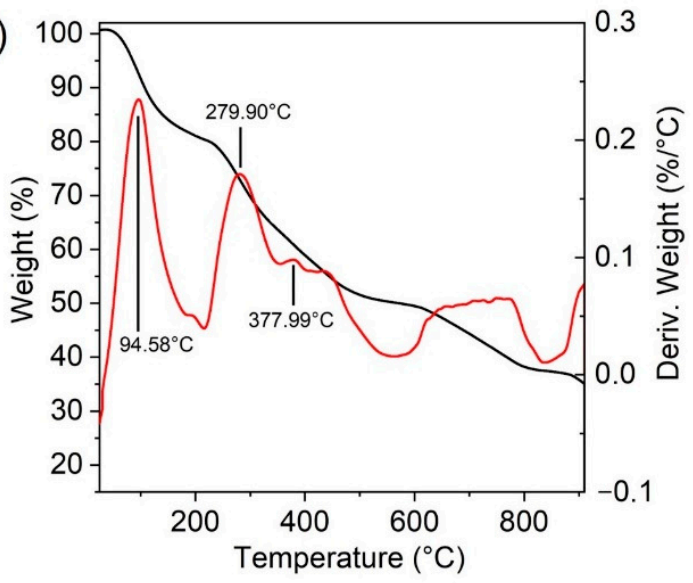

(b)

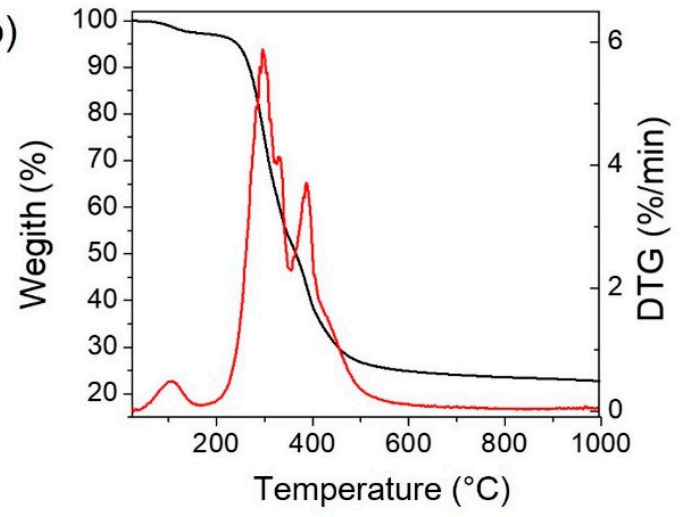

(d)

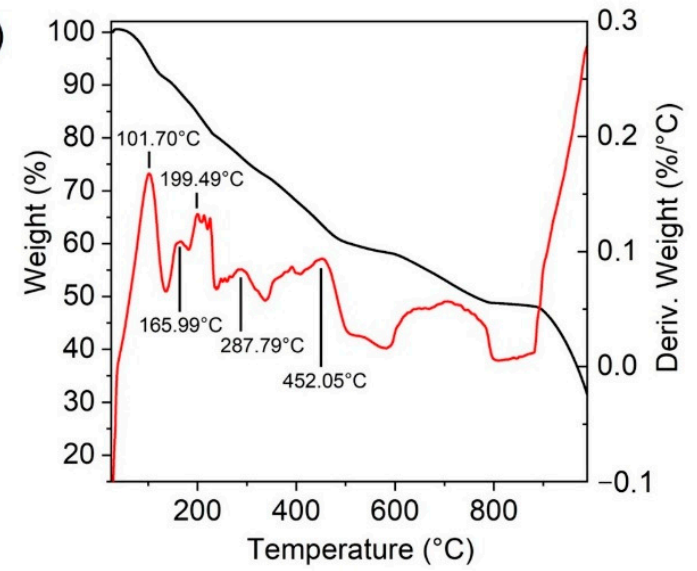

Figure 3. Thermogravimetric (TG) and derivative thermogravimetric (DTG) profile of (a) sample R in the range $30-1000{ }^{\circ} \mathrm{C}$ $\left(10^{\circ} \mathrm{C} / \mathrm{min}\right)$ under $\mathrm{N}_{2},(\mathbf{b})$ sample $\mathrm{A}$ in the range $30-1000{ }^{\circ} \mathrm{C}\left(10^{\circ} \mathrm{C} / \mathrm{min}\right)$ under $\mathrm{N}_{2} ;$ (c) the mixture $\mathrm{R} / \mathrm{KOH} 1 / 1$ in the range $30-1000{ }^{\circ} \mathrm{C}$ at $10{ }^{\circ} \mathrm{C} /$ min under $\mathrm{N}_{2} ;(\mathrm{d})$ the mixture $\mathrm{A} / \mathrm{KOH} 1 / 1$ in the range $30-1000{ }^{\circ} \mathrm{C}$ at $10^{\circ} \mathrm{C} / \mathrm{min}$ under $\mathrm{N}_{2}$.

In both cases most of the material loss was observed at about $380{ }^{\circ} \mathrm{C}$. Thus, in a separate experiment the A raw material was heated at $380^{\circ} \mathrm{C}$ for $6 \mathrm{~h}$ under nitrogen: the brownish oil residue formed was dissolved in acetone and a GC/MS analysis showed the presence of methyl and ethyl esters of palmitic and stearic acid together with a lower amount of caffeine (Figure S5a). From the experiment also a black material was achieved, formed by a spongy and a powder fraction, whose morphology has been reported in Figure $\mathrm{S} 5 \mathrm{~b}$ (the $\mathrm{C}$ content was about $85 \%$ ).

In Figure $3 c, d$, the TG and DTG profiles of the mixtures R/KOH $1 / 1$ and $\mathrm{A} / \mathrm{KOH} 1 / 1$ have been reported: they were completely different from those of $\mathrm{R}$ and $\mathrm{A}$, alone, with a sequence of different degradation and loss processes. On the basis of the data reported in the literature $[59,65-67]$ we could divide the thermal degradation of the mixtures into four steps: in the first one, ranging from ambient temperature to about $150{ }^{\circ} \mathrm{C}$, a weight loss of $10-15 \%$ occurred due to water and initial $\mathrm{H}_{2}$ evolution; in the second step, from 150 to $350{ }^{\circ} \mathrm{C}$, with a weight loss of $15-20 \%$, the initial formation of $\mathrm{C} 2$ hydrocarbons and $\mathrm{CH}_{4}$ and of water from dehydration of biopolymers could occur together with the initiation of carbonization; increasing the temperature in the range $350-800{ }^{\circ} \mathrm{C}$, a weight loss of about $25 \%$ was observed due to evolution of $\mathrm{CO}, \mathrm{CO}_{2}, \mathrm{CH}_{4}, \mathrm{C}_{2} \mathrm{H}_{4}$, and $\mathrm{C}_{2} \mathrm{H}_{6}$ originated by the $\mathrm{C}-\mathrm{C}$ and $\mathrm{C}-\mathrm{H}$ bonds break to give radicals which can be recombined into small molecules, during the aromatization of the matrix and carbonization which can be completed at about $600^{\circ} \mathrm{C}$. In this frame, further studies will be carried out by TG-MS either changing the mixture composition and the heating rate. In the range $800-900{ }^{\circ} \mathrm{C}$ the completion of the aromatization occurred. 


\subsection{Chemical Characterization of the Activated Carbons}

As reported above, a series of activated carbons have been prepared from two different spent coffee grounds through pyrolytic process at different temperatures and in the presence of different activator agents (i.e., $\mathrm{KOH}, \mathrm{K}_{2} \mathrm{CO}_{3}, \mathrm{ZnCl}_{2}, \mathrm{NaHCO}_{3}$ ) according to Scheme 2. The characterization of the ACs was carried out using different analytical techniques able to determine chemical, physical, and morphological properties, and the data were compared with those of three commercial carbons used in water decontamination plants.

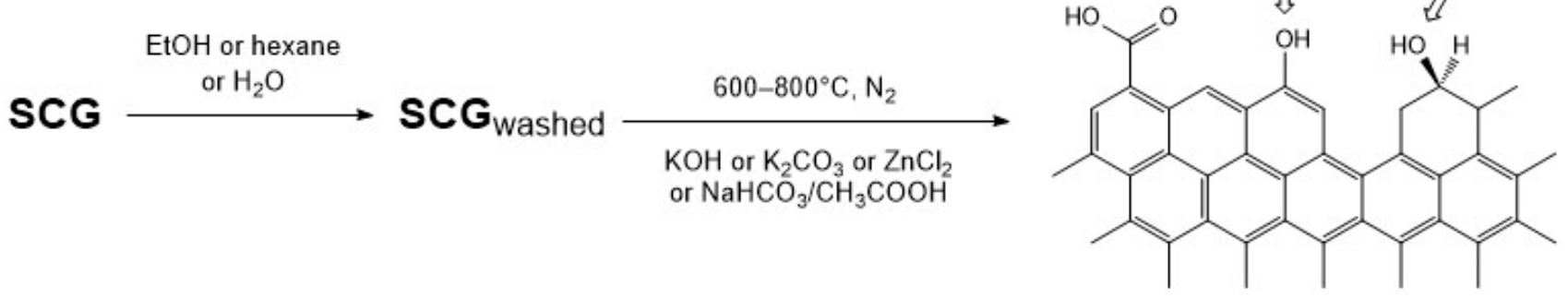

Scheme 2. Preparation process of the activated carbons.

\subsubsection{Fourier Transform Infrared (FT-IR) and Raman Data}

Significant changes were observed in the RACs and AACs FT-IR spectra (Figure 2) with respect those of the starting SCGs. The FT-IR spectra of the carbons (in Figure 2 the FT-IR spectrum of the commercial M sample was reported, too) showed no significant peaks in the $v_{\mathrm{C}-\mathrm{H}}$ region, indicating that organic compounds were degraded or removed from the char during the heating process. New bands were observed at about 3400 and $1080 \mathrm{~cm}^{-1}$ assigned to $\mathrm{O}-\mathrm{H}$ and $\mathrm{C}-\mathrm{OH}$ stretching of phenolic groups, respectively, due to the alkaline treatment. In addition, carbon skeleton vibrations characteristic of ACs in the $1600-1400 \mathrm{~cm}^{-1}$ region could be observed [68-70].

To achieve deeper information concerning the carbonization degree and the microstructure of the ACs, a detailed analysis of the Raman spectra has been carried out. All the Raman spectra (Figure S6) showed [71-77] signals in two distinct regions: (a) the defectderived peak centered at about $1350 \mathrm{~cm}^{-1}$ related to a disordered (amorphous) carbon structure (the D-band, related to the K-point phonons of $\mathrm{A}_{1 \mathrm{~g}}$ symmetry, indicating the disorder in the breathing mode of the 6-fold aromatic ring near the basal edge) and the graphite structure-derived (G-band, related to the zone center phonons of $E_{2 g}$ symmetry) peak centered at about $1570 \mathrm{~cm}^{-1}$ indicative of a hexagonal carbon structure; and (b) a broad absorption centered at about $2800 \mathrm{~cm}^{-1}$, the $2 \mathrm{D}$ or $\mathrm{G}^{\prime}$ band, related to the interactions between the stacked graphitic layers. In Figure 4, the Raman spectrum of the AAC-6 sample has been reported together with the deconvolution of the signals with the components of the bands, which could give useful structural information. 


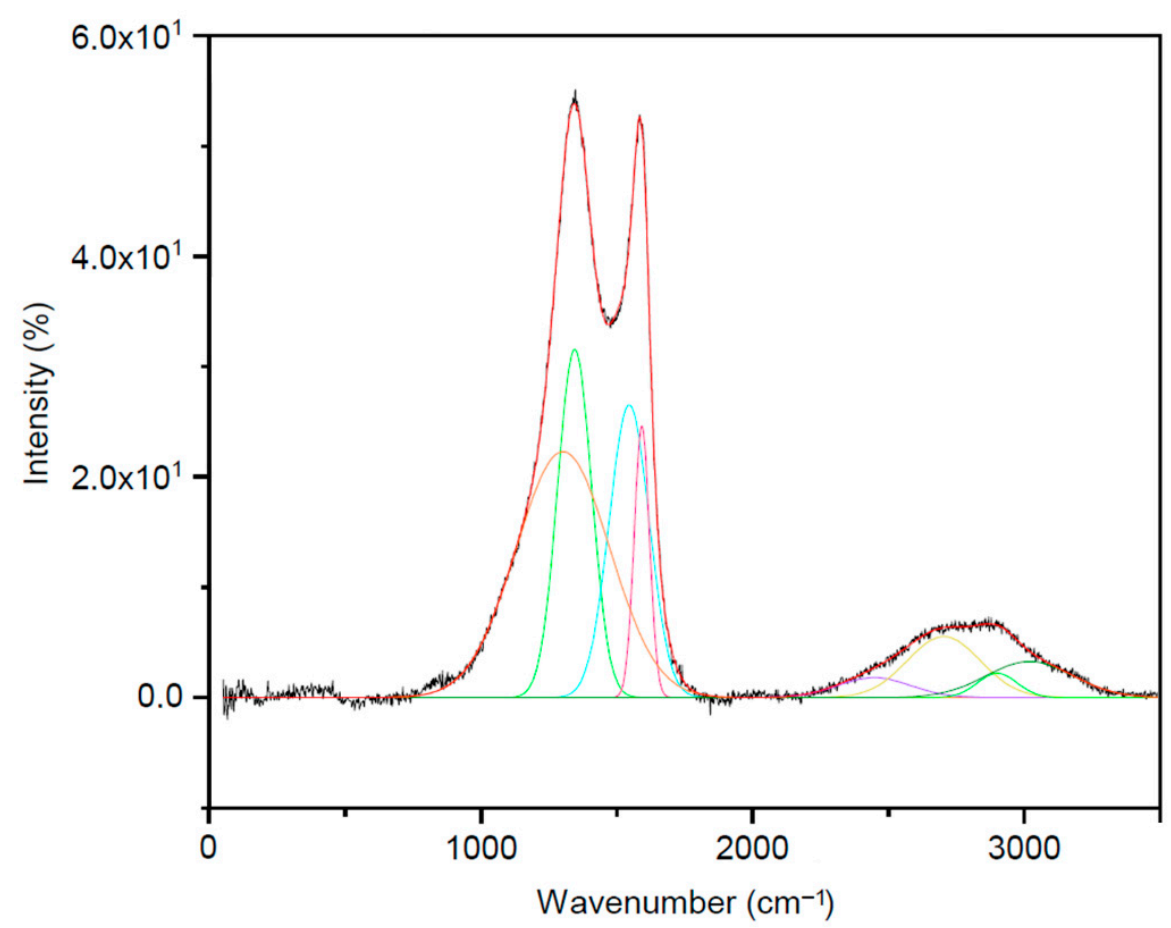

Figure 4. Raman spectrum of the AAC-6 sample together with the deconvolution.

In Table S3 the parameters obtained from fitting two Gaussians as G and D bands to the Raman spectra of the ACs samples have been reported together with the peak intensity ratio $\mathrm{I}_{\mathrm{D}} / \mathrm{I}_{\mathrm{G}}$ which indicates the carbonization degree and the amount of defective (amorphous) carbon structures induced by activation. The higher the $\mathrm{I}_{\mathrm{D}} / \mathrm{I}_{\mathrm{G}}$ value, the higher the distortion of $\mathrm{sp}^{2}$ rings in the material [71-77].

In Table S4 the fitting parameters obtained from further deconvolution of the $\mathrm{G}$ and $\mathrm{D}$ bands have been reported together with the peak intensity ratio $\mathrm{I}_{\mathrm{D} 1} / \mathrm{I}_{\mathrm{G} 1}, \mathrm{I}_{\mathrm{D} 2} / \mathrm{I}_{\mathrm{G} 2}$ and $\mathrm{I}_{\mathrm{G} 2} / \mathrm{I}_{\mathrm{G} 1}$ which can give information concerning the size of the basal plane, the relative $\mathrm{sp}^{2} / \mathrm{sp}^{3}$ bonding ratio and a relative content of the bond angle disorder in $\mathrm{AC}$ materials.

A similar treatment has been devoted to the signals in the Raman spectra in the 2D region, as shown in Figure 4 and reported in Table S5.

Much structural information can be obtained from the Raman spectra. The activated carbons can be schematically considered formed by two structural parts: one is winding short basal plane with bond angle order represented by a pair of sharp G1 and D1 bands, and the other is $\mathrm{sp}^{2}$-cluster like amorphous-carbons with bond angle disorder represented by a pair of broad G2 and D2 bands. Some correlations have been proposed in the literature [72,73] and have been studied for our samples, too.

In Figure 5, where $v$ and FWHM of all the samples have been reported, we could observe that D1, G1 and G2 were in well-defined domains, while D2 resulted more distributed:

(a) the G1 position is quite stable: for RACs in the range $1589-1599 \mathrm{~cm}^{-1}$ (FWHM of $66.5 \pm 3.5 \mathrm{~cm}^{-1}$ ) and for AACs in the range 1592-1603 $\mathrm{cm}^{-1}$ (FWHM of $68 \pm 7 \mathrm{~cm}^{-1}$ );

(b) the D1 position is quite stable: for RACs in the range $1342-1352 \mathrm{~cm}^{-1}$ (FWHM of $140.5 \pm 13.5 \mathrm{~cm}^{-1}$ ) and for AACs in the range 1344-1354 $\mathrm{cm}^{-1}$ (FWHM of $164 \pm 20 \mathrm{~cm}^{-1}$ );

(c) the G2 position is less stable and the signals are broader: for RACs in the range $1531-1555 \mathrm{~cm}^{-1}$ (FWHM of $174.5 \pm 4.5 \mathrm{~cm}^{-1}$ ) and for AACs in the range $1540-1565 \mathrm{~cm}^{-1}$ (FWHM of $172 \pm 11 \mathrm{~cm}^{-1}$ );

(d) the D2 position is significantly less stable and the signals are broader: for RACs in the range $1140-1350 \mathrm{~cm}^{-1}$ (FWHM of $272 \pm 80 \mathrm{~cm}^{-1}$ ) and for AACs in the range $1199-1333 \mathrm{~cm}^{-1}$ (FWHM of $\left.321 \pm 87 \mathrm{~cm}^{-1}\right)$. 


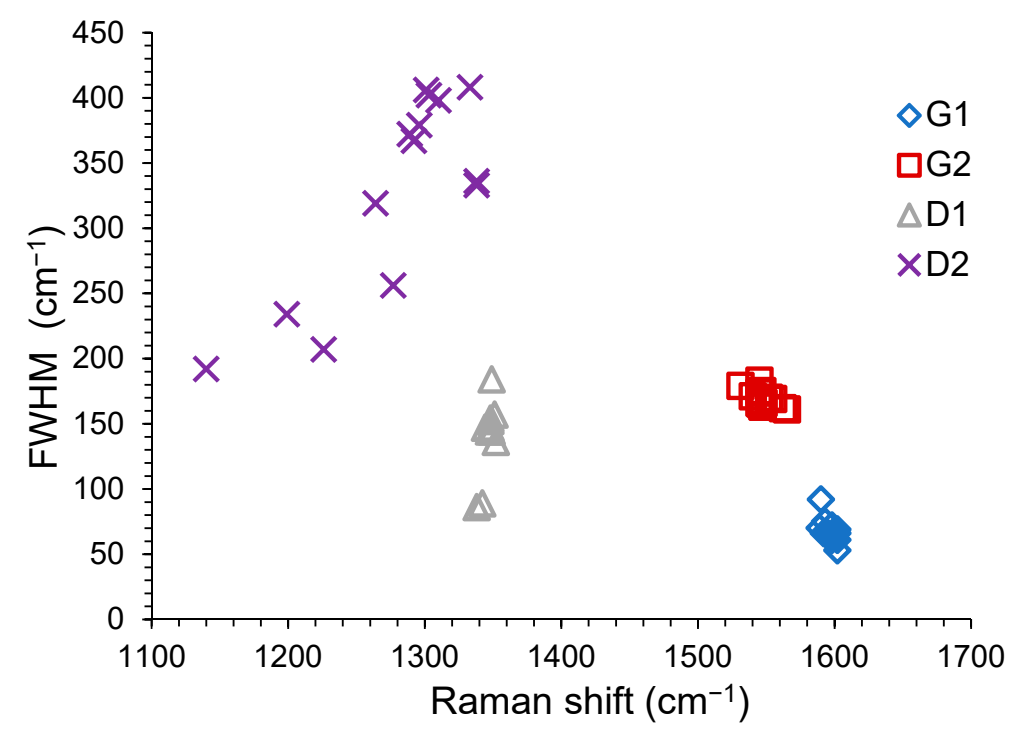

Figure 5. Position of the different bands (G1, G2, D1, D2) in function of their FWHM.

\subsubsection{X-ray Diffraction (XRD) and X-ray Photoelectron Spectroscopy (XPS)}

Microstructures of ACs were analyzed via XRD. The XRD pattern (some of them have been reported in Figure 6, and the other in Figure S7) of all the ACs samples exhibited two very broad bands at about $24^{\circ}$ and $43^{\circ}$ corresponding to planar graphite (002), indicating the degree of carbon layer stacking and (100) indicating the degree of ordered hexagonal carbon structures, respectively. The extreme broadening of the (002) peak indicated a carbon layer exfoliation via potassium during the pyrolysis process, particularly for samples RAC-1, AAC-1, AAC-6 compared with the XRD spectrum of the commercial C sample.

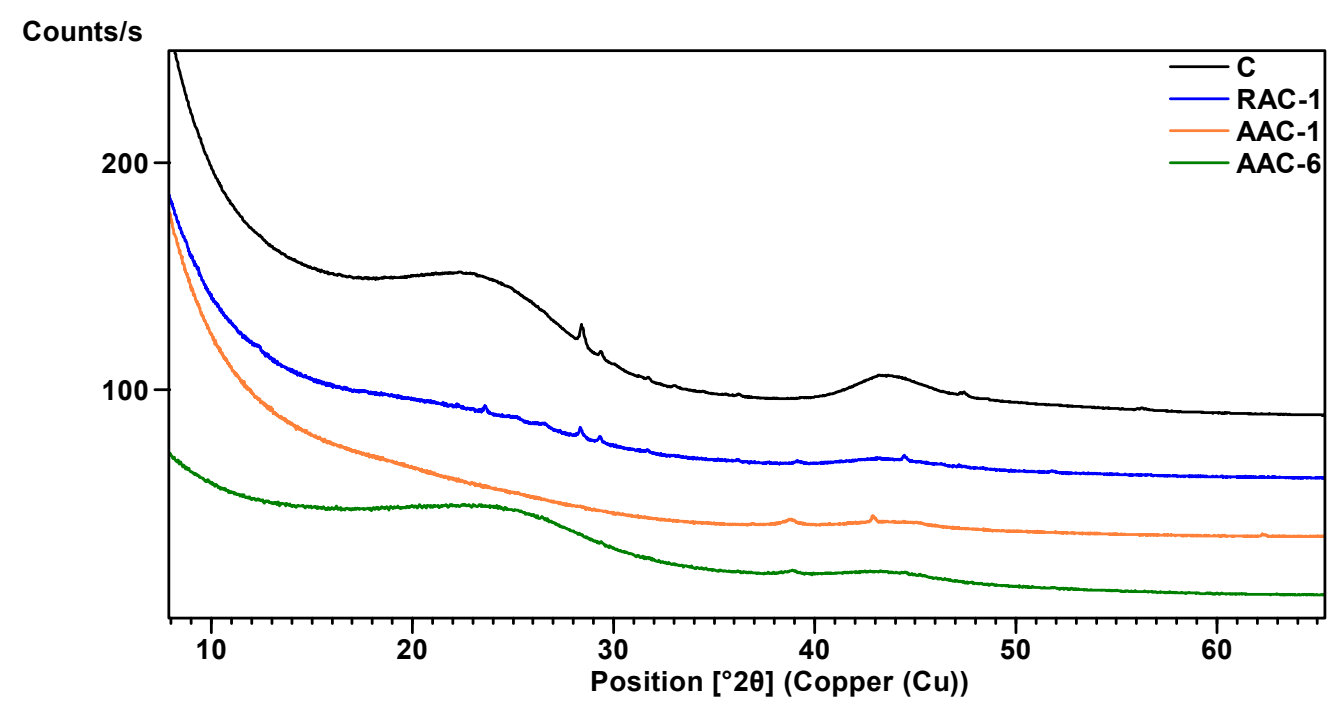

Figure 6. X-ray diffraction (XRD) spectra of the samples RAC-1, AAC-1, AAC-6 and C.

The broadening increases with an increase in specific surface area [43], even if no good correlation have been detected between BET and XRD data for all our samples. Upon $\mathrm{KOH}$ activation the diffraction peaks for (100) had a smaller effect than the diffraction peaks for (002). The average interlayer $d_{\text {spacing }} 002$ (from 0.37 to $0.39 \mathrm{~nm}$ ) and average crystalline diameter Lc were calculated from the diffraction patterns (Table 4). 
Table 4. Average interlayer $\mathrm{d}_{\text {spacing }} 002$ and 100; average crystalline diameter Lc calculated from the analysis of the XRD spectra.

\begin{tabular}{|c|c|c|c|c|}
\hline Sample & $\begin{array}{c}\text { Size Lc } 002 \\
\text { (̊) }\end{array}$ & $\begin{array}{l}\text { Size Lc } 100 \\
\text { (A) }\end{array}$ & $\begin{array}{c}\mathrm{d}_{\text {spacing }} 002 \\
\text { (Å) }\end{array}$ & $\mathrm{d}_{\text {spacing }} 100$ \\
\hline RAC-1 & 0.7 & 1.7 & 3.780 & 2.078 \\
\hline RAC-2 & 0.8 & 1.7 & 3.795 & 2.060 \\
\hline RAC-3 & 0.9 & 1.9 & 3.750 & 2.081 \\
\hline RAC-4 & 1.2 & 1.8 & 3.760 & 2.062 \\
\hline $\mathrm{AAC}^{-1}{ }^{1}$ & - & 1.7 & - & 2.065 \\
\hline AAC-2 & 1.3 & 2.0 & 3.740 & 2.076 \\
\hline AAC-3 & 0.8 & 1.1 & 3.798 & 2.061 \\
\hline AAC-4 & 1.1 & 1.8 & 3.839 & 2.071 \\
\hline AAC-5 & 1.0 & 1.3 & 3.739 & 2.081 \\
\hline AAC-6 & 0.9 & 1.5 & 3.716 & 2.081 \\
\hline AAC-7 & 1.0 & 1.9 & 3.691 & 2.078 \\
\hline AAC-8 & 0.8 & 1.6 & 3.792 & 2.074 \\
\hline AAC-9 & 0.9 & 1.2 & 3.776 & 2.085 \\
\hline AAC-10 & 0.8 & 1.4 & 3.749 & 2.088 \\
\hline $\mathbf{M}$ & 0.8 & 2.0 & 3.536 & 2.068 \\
\hline $\mathrm{C}$ & 1.1 & 2.2 & 3.759 & 2.073 \\
\hline LP39 & 1.1 & 1.5 & 3.874 & 2.099 \\
\hline
\end{tabular}

${ }^{1}$ Too broad to be calculated.

The surface properties of the ACs samples were characterized via X-ray photoelectron spectroscopy spectra, and as shown in Figure $\mathrm{S} 8$ for some samples the signals have been deconvoluted to achieve the data reported in Tables 5 and 6 , for $\mathrm{C} 1 \mathrm{~s}$ and $\mathrm{O} 1 \mathrm{~s}$, respectively. In the XPS C 1s spectra, $\mathrm{C}-\mathrm{O}$ were centered at $285.8 \mathrm{eV}, \mathrm{C}=\mathrm{O}$ at $286.7 \mathrm{eV}$ and $\mathrm{C}(\mathrm{O}) \mathrm{O}$ at $288.1 \mathrm{eV}$ with a main $\mathrm{C}=\mathrm{C}$ bond centered at $284.4 \mathrm{eV}$; this position decreases towards lower values (around 283.9-284.0 eV) for nanometric sized particles. For some samples a signal at $290.1 \mathrm{eV}$ was observed, which can be attributed to carbons in a carbonate environment, in agreement with the presence of an absorption at $872 \mathrm{~cm}^{-1}$ in the FT-IR spectra, characteristic of carbonate moiety [78]. Additionally, $\mathrm{C}=\mathrm{O}$ and $\mathrm{C}-\mathrm{O}$ bonds centered at $532.2 \mathrm{eV}$ and $531.0 \mathrm{eV}$, respectively, were evident in the $\mathrm{O} 1 \mathrm{~s}$ spectra. The $\mathrm{N} 1 \mathrm{~s}$ signal is not always detectable and is characterized by a low $\mathrm{W} / \mathrm{N}$ ratio. The peak centroid, however, ranges around $399.5 \mathrm{eV}$, consistently with the presence of pyrrolic species [57]. It is noteworthy that the compositional data from the XPS measurements agree with the results achieved by elemental analysis and XRF (Table S6) [79].

Table 5. Intensities of the C1s X-ray photoelectron spectroscopy (XPS) signals. All the values have been obtained from the average of three measurements in different regions of each sample.

\begin{tabular}{ccccccc}
\hline Sample & $\begin{array}{c}\mathrm{C}=\mathrm{C} \mathrm{sp}^{\mathbf{2}} \\
\sim \mathbf{2 8 4 . 4} \mathbf{~ e V}\end{array}$ & $\begin{array}{c}\mathrm{C}-\mathrm{C} \mathrm{sp} \\
\sim \mathbf{2 8 5 . 2} \mathbf{~ e V}\end{array}$ & $\begin{array}{c}\mathrm{C}-\mathrm{OH} \\
\sim \mathbf{2 8 5 . 8} \mathbf{~ e V}\end{array}$ & $\begin{array}{c}\mathrm{C}=\mathrm{O} \\
\sim \mathbf{2 8 6 . 7} \mathbf{e V}\end{array}$ & $\begin{array}{c}\mathrm{O}-\mathrm{C}=\mathrm{O} \\
\sim \mathbf{2 8 8 . 1} \mathbf{~ e V}\end{array}$ & $\begin{array}{c}\mathbf{C O}_{3}{ }^{2-} \\
\sim \mathbf{2 9 0 . 1} \mathbf{~ e V}\end{array}$ \\
\hline RAC-1 & 57.5 & 9.2 & 9.3 & 8.2 & 5.3 & 10.6 \\
\hline RAC-2 & 41.9 & 34.6 & 11.6 & 3.7 & 4.9 & 3.4 \\
\hline RAC-4 & 37.4 & 32.6 & 7.1 & 12.7 & 6.2 & 4.0 \\
\hline AAC-1 & 51.9 & 14.9 & 6.7 & 8.3 & 5.4 & 12.8 \\
\hline AAC-2 & 48.0 & 26.3 & 11.6 & 8.6 & 5.5 & - \\
\hline
\end{tabular}


Table 5. Cont.

\begin{tabular}{|c|c|c|c|c|c|c|}
\hline Sample & $\begin{array}{c}\mathrm{C}=\mathrm{C} \mathrm{sp}^{2} \\
\sim 284.4 \mathrm{eV}\end{array}$ & $\begin{array}{c}\mathrm{C}-\mathrm{C} \mathrm{sp}^{3} \\
\sim 285.2 \mathrm{eV}\end{array}$ & $\begin{array}{c}\mathrm{C}-\mathrm{OH} \\
\sim 285.8 \mathrm{eV}\end{array}$ & $\begin{array}{c}\mathrm{C}=\mathrm{O} \\
\sim 286.7 \mathrm{eV}\end{array}$ & $\begin{array}{c}\mathrm{O}-\mathrm{C}=\mathrm{O} \\
\sim 288.1 \mathrm{eV}\end{array}$ & $\begin{array}{c}\mathrm{CO}_{3}{ }^{2-} \\
\sim 290.1 \mathrm{eV}\end{array}$ \\
\hline AAC-3 & 46.8 & 24.6 & 11.7 & 9.6 & 7.3 & - \\
\hline AAC-4 & 56.4 & 7.1 & 11.2 & 8.7 & 5.9 & 10.7 \\
\hline AAC-5 & 55.1 & 13.0 & 10.1 & 8.3 & 5.7 & 7.8 \\
\hline AAC-6 & 54.4 & 12.0 & 9.4 & 10.3 & 5.6 & 8.3 \\
\hline AAC-7 & 59.6 & 12.2 & 9.2 & 6.0 & 5.2 & 7.8 \\
\hline AAC -8 * & 46.7 & 24.6 & 11.7 & 9,6 & 7.3 & - \\
\hline AAC-9 & 37.3 & 36.8 & 9.5 & 5.6 & 3.9 & 6.9 \\
\hline AAC-10 & 48.6 & 28.9 & 12.4 & 5.6 & 4.5 & - \\
\hline $\mathbf{M}$ & 57.6 & 17.3 & 5.7 & 6.6 & 3.1 & 9.7 \\
\hline $\mathrm{C}$ & 47.2 & 28.5 & 18.1 & 6.2 & - & - \\
\hline LP39 & 42.8 & 34.7 & 8.5 & 4.6 & 3.8 & 5.7 \\
\hline
\end{tabular}

* An additional signal at $292.8 \mathrm{eV}(2.7)$ is present.

Table 6. Intensities of the O1s XPS signals. All the values have been obtained from the average of three measurements in different regions of each sample.

\begin{tabular}{cccc}
\hline Sample & $\begin{array}{c}\mathbf{C s p}^{\mathbf{3}-\mathbf{O H}} \\
\mathbf{5 3 1 . 0} \mathbf{~ e V}\end{array}$ & $\begin{array}{c}\mathbf{C}=\mathbf{O} \\
\mathbf{5 3 2 . 2} \mathbf{~ e V}\end{array}$ & $\begin{array}{c}\mathbf{C}_{\text {Ar- }} \mathbf{O H} \\
\mathbf{5 3 3 . 5} \mathbf{~ e V}\end{array}$ \\
\hline RAC-1 & 22.0 & 41.0 & 37.0 \\
\hline RAC-2 & 33.8 & 43.0 & 23.2 \\
\hline RAC-4 & 19.9 & 33.3 & 46.8 \\
\hline AAC-1 & 12.7 & 51.1 & 36.2 \\
\hline AAC-2 $\mathbf{1}^{\mathbf{1}}$ & 29.7 & 40.1 & 29.4 \\
\hline AAC-3 & 22.1 & 40.9 & 28.4 \\
\hline AAC-4 & 25.2 & 48.3 & 26.5 \\
\hline AAC-5 & 22.9 & 52.2 & 24.8 \\
\hline AAC-6 & 25.8 & 42.1 & 32.0 \\
\hline AAC-7 & 33.6 & 44.7 & 21.7 \\
\hline AAC-8 & 41.2 & 39.5 & 19.4 \\
\hline AAC-9 & 35.9 & 49.8 & 22.9 \\
\hline AAC-10 & 30.5 & 46.6 & 29,8 \\
\hline M & 4,8 & 65,4 & 19.1 \\
\hline C & 26.6 & 54.3 & 18.4 \\
\hline LP39 & 34.5 & 47.1 & \\
\hline
\end{tabular}

${ }^{1}$ An additional signal at $535.1 \mathrm{eV}$ is present due to O1s satellites and the possible contribution from carbonate.

It is observed that carbon structures were manly composed of major $\mathrm{C}=\mathrm{C}$ bonding and minor $\mathrm{C}-\mathrm{C}$. No adsorbed water on the ACs surfaces was observed in $\mathrm{O} 1 \mathrm{~s}$ spectra.

\subsection{3. ${ }^{13} \mathrm{C}$ Nuclear Magnetic Resonance (NMR)}

The ${ }^{13} \mathrm{C}$ NMR in the solid state of the activated carbons prepared reported in Figure S9, showed that the structure of the raw materials was completely transformed into a polycyclic material exhibiting the typical aromatic broad signal centered at about 125-130 ppm [80-82].

It is noteworthy that for samples AAC-9, $\mathrm{M}$ and $\mathrm{C}$ it was not possible to tune the ${ }^{1} \mathrm{H}$ NMR frequency, thus ${ }^{13} \mathrm{C}$ MAS-NMR spectra were not ${ }^{1} \mathrm{H}$-decoupled. This effect was 
tentatively attributed to the presence of a high amount of adsorbed oxygen, but after long and repeating degassing processes of the samples the effect was still present. For this reason, it was explained with a conductive behavior of the samples, which was measured for columns (piston diameter $5.9 \mathrm{~mm}$; column height before pressure $19 \mathrm{~mm}$ for $\mathrm{M}, 25 \mathrm{~mm}$ for $\mathrm{C}$ and $33 \mathrm{~mm}$ for AAC-9) of the samples under different applied pressures. The effect was cited in the literature, and will deserve further investigation in our samples, for application of activated carbons in electrochemical devices (Figure 7) [83,84]. It could be observed that the $\delta$ value for AAC-10 resulted significantly lower than that of the AAC-9, $\mathrm{M}$ and $\mathrm{C}$, samples.

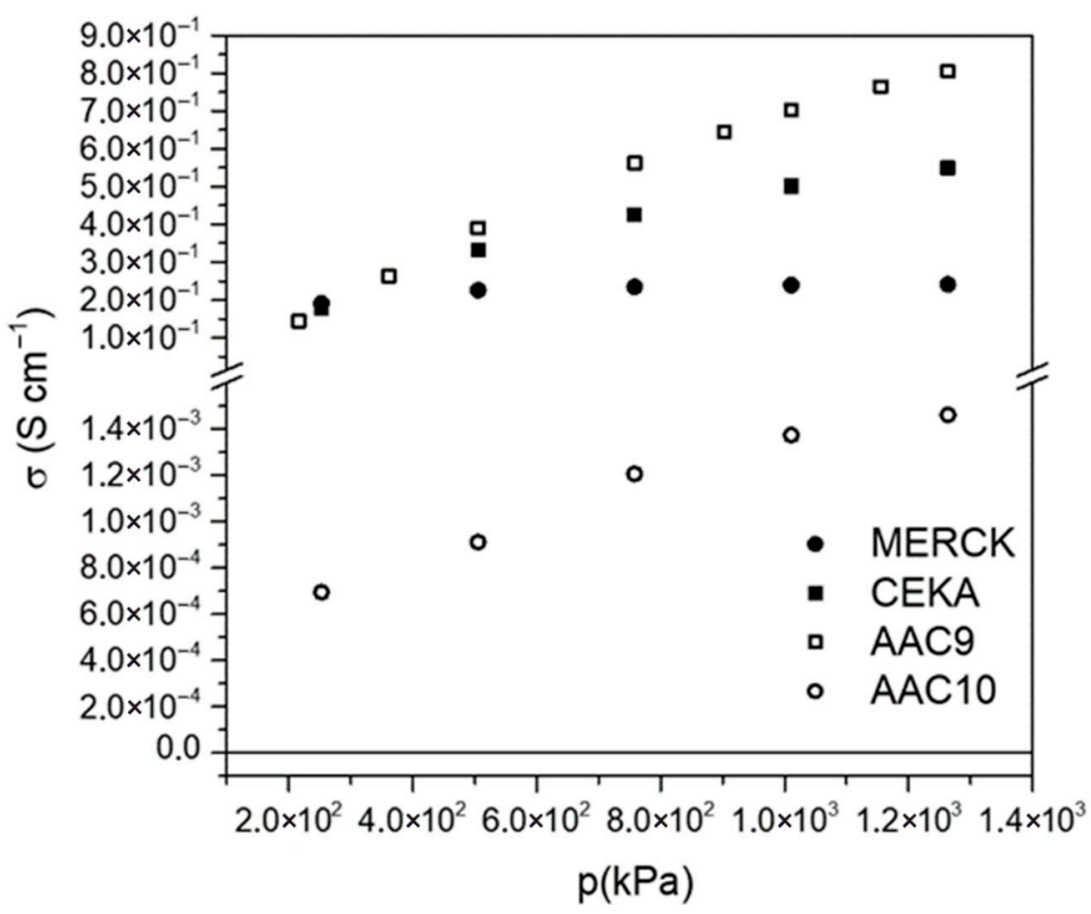

Figure 7. Electrical conductivity measured for columns of samples of fixed dimensions under different applied pressures.

\subsubsection{Surface Chemistry Characterization}

Table 7 shows quantitative surface chemical analyses in terms of amount of acid and basic functional groups of ACs. There is a slight predominance of acid or basic groups depending on the preparation. The presence of phenolic groups agrees with the FT-IR and XPS data $[60,85-87]$. In the case of the tested samples prepared in the presence of $\mathrm{KOH}$ as activating agent (AAC-5, -6, -7, -9), the predominance of basic moieties can be observed. Note the different behavior of the commercial samples, reasonably obtained under different experimental conditions.

Table 7. Results of Bohem titration.

\begin{tabular}{cccccc}
\hline Sample & $\begin{array}{c}\text { Carboxylic } \\
(\mathbf{m m o l} / \mathbf{g})\end{array}$ & $\begin{array}{c}\text { Lactonic } \\
(\mathbf{m m o l} / \mathbf{g})\end{array}$ & $\begin{array}{c}\text { Phenolic } \\
(\mathbf{m m o l} / \mathbf{g})\end{array}$ & $\begin{array}{c}\text { Acidic } \\
(\mathbf{m m o l} / \mathbf{g})\end{array}$ & $\begin{array}{c}\text { Basic } \\
(\mathbf{m m o l} / \mathbf{g})\end{array}$ \\
\hline AAC-5 & 1.71 & 0 & 0.80 & 2.34 & 2.51 \\
\hline AAC-6 & 2.80 & 0 & 0.10 & 2.79 & 2.90 \\
\hline AAC-7 & 2.77 & 0 & 0.03 & 2.80 & 0.50 \\
\hline AAC-9 & 0.05 & 0 & 0.45 & 0.10 & 0.60 \\
\hline M & 0 & 0 & 0.10 & 0 & 0.70 \\
\hline C & 0 & 0 & 0 & 1.00 & 0 \\
\hline LP39 & 0.49 & 0 & 0.51 &
\end{tabular}




\subsection{Physical and Textural Characterization}

\subsubsection{Brunauer-Emmett-Teller (BET) Analysis and Pore Size Distribution}

In Figure $\mathrm{S} 10$ selected $\mathrm{N}_{2}$ absorption isotherm profiles have been reported, and the specific surface area data are shown in Table 8. The curves for the series RAC and AAC show similar trends, with type I shape, typical of microporous materials, as evidenced by the steep adsorption increase at low pressure. In fact, the mesopore fraction is quite low with respect to the micropore amount, as evidenced by the ratio $V_{m} / V_{\text {tot }}$ where $V_{m}$ is estimated as $V_{\text {tot }}-V_{\mu}\left(V_{\mu}\right.$ derived from t-plot regression), as previously reported for $\mathrm{KOH}$ activated carbon from waste coffee beans. [88] Nevertheless, the BJH model has been applied to the desorption branch to derive the pore size distribution of this small fraction of mesopores and in the sample RAC-3 the distribution is structureless and a maximum is not visible, while for AAC-9 it is found at around $4 \mathrm{~nm}$. In the case of LP39 (a commercial activated carbon of unknown preparation), the isotherm belongs to type IV, showing both the steep adsorption in the low-pressure regime, indicating micropores, and the hysteresis loop typical of mesoporous materials. The fraction of mesopores over total pores is $70 \%$ and the pore size distribution has a maximum at $9 \mathrm{~nm}$.

Table 8. Physical properties of ACs from coffee grounds by different activation conditions.

\begin{tabular}{|c|c|c|c|c|c|c|}
\hline Sample & $\begin{array}{c}S_{\text {BET }} \\
\left(\mathrm{m}^{2} / \mathrm{g}\right)\end{array}$ & $\begin{array}{c}V_{t} \\
\left(\mathrm{~cm}^{3} / \mathrm{g}\right)\end{array}$ & $\underset{\left(\mathrm{cm}^{3} / \mathrm{g}\right)}{V_{\mathrm{m}}}$ & $\begin{array}{c}V_{\mu} \\
\left(\mathrm{cm}^{3} / \mathrm{g}\right)\end{array}$ & $\begin{array}{c}\mathrm{V}_{\mu} / \mathrm{V}_{\mathrm{t}} \\
(\%)\end{array}$ & $\underset{(\mathrm{nm})}{\mathrm{D}_{\mathrm{p}}}$ \\
\hline RAC-1 & 629 & 0.30 & 0.06 & 0.24 & 80.0 & 1.69 \\
\hline RAC-2 & 765 & 0.32 & 0.05 & 0.27 & 84.8 & 1.64 \\
\hline RAC-3 & 478 & 0.20 & 0.03 & 0.17 & 85.0 & 1.69 \\
\hline RAC-4 & 367 & 0.15 & 0.02 & 0.13 & 86.7 & 1.61 \\
\hline AAC-1 & 1407 & 0.76 & 0.08 & 0.68 & 89.5 & 2.16 \\
\hline AAC-2 & 1362 & 0.72 & 0.11 & 0.61 & 84.7 & 2.13 \\
\hline AAC-3 & 1868 & 1.06 & 0.44 & 0.62 & 58.5 & 2.27 \\
\hline AAC-4 & 1535 & 0.82 & 0.12 & 0.70 & 85.4 & 2.14 \\
\hline AAC-5 & 615 & 0.32 & 0.01 & 0.31 & 96.9 & 2.10 \\
\hline AAC- 6 & 1715 & 0.92 & 0.07 & 0.85 & 92.4 & 2.14 \\
\hline AAC-7 & 1375 & 0.74 & 0.07 & 0.67 & 90.5 & 2.14 \\
\hline AAC-8 & 721 & 0.31 & 0.01 & 0.30 & 96.8 & 2.12 \\
\hline AAC-9 & 1200 & 0.50 & 0.07 & 0.43 & 86.0 & 1.67 \\
\hline AAC-10 & 495 & 0.27 & 0.01 & 0.26 & 96.3 & 2.18 \\
\hline $\mathbf{M}$ & 823 & 0.52 & 0.14 & 0.38 & 73.1 & 2.54 \\
\hline $\mathrm{C}$ & 932 & 0.49 & 0.04 & 0.45 & 91.9 & 2.11 \\
\hline LP39 & 1782 & 1.62 & 1.14 & 0.51 & 31.5 & 3.64 \\
\hline
\end{tabular}

$\mathrm{S}_{\mathrm{BET}}=\mathrm{BET}$ surface area. $\mathrm{V}_{\mathrm{t}}=$ total pore volume. $\mathrm{V}_{\mu}=$ micropore volume. $\mathrm{V}_{\mathrm{m}}=$ mesopore volume

$\mathrm{V}_{\mu} / \mathrm{V}_{\mathrm{t}}=$ percentage of micropores. $\mathrm{D}_{\mathrm{p}}=$ average pore diameter.

Considering the specific surface area, it was observed that the highest values have been obtained through processes carried out at $800{ }^{\circ} \mathrm{C}$ in the presence of $\mathrm{NaHCO}_{3} / \mathrm{CH}_{3} \mathrm{COOH}$. In the case of activation with $\mathrm{KOH}$, in agreement with the data reported in the literature $[57,89]$, the highest BET value can be achieved by pyrolysis of SCGs at $700{ }^{\circ} \mathrm{C}$, even without a preliminary treatment with $\mathrm{KOH}_{\mathrm{aq}}$.

The nature of the activator and preparation conditions strongly influence the final physical, chemical and morphological properties of activated carbons from biomasses [90]: of specific relevance is the tuning of the experimental conditions to achieve hierarchically mesoporous/microporous carbon materials $[91,92]$ due to the wide variety of possible applications. 
3.4.2. Environmental Scanning Electron Microscopy (ESEM) and Transmission Electron Microscopy (TEM)

ESEM images of the raw material A and of the AAC-5, AAC-6 and AAC-7 have been reported in Figure 8. Progressive surface changes can be observed. The surface of the raw material is homogeneous without any porous structure. Nevertheless, major surface damage appeared when the raw material was carbonized due to the release of volatile compounds, with a porosity strongly depending on the experimental conditions, temperature, and activator agent, as indicated by the BET values and textures (Figures S10 and S11), with the formation of holes and channels, in agreement with the microporous nature of the samples [93].

(a)

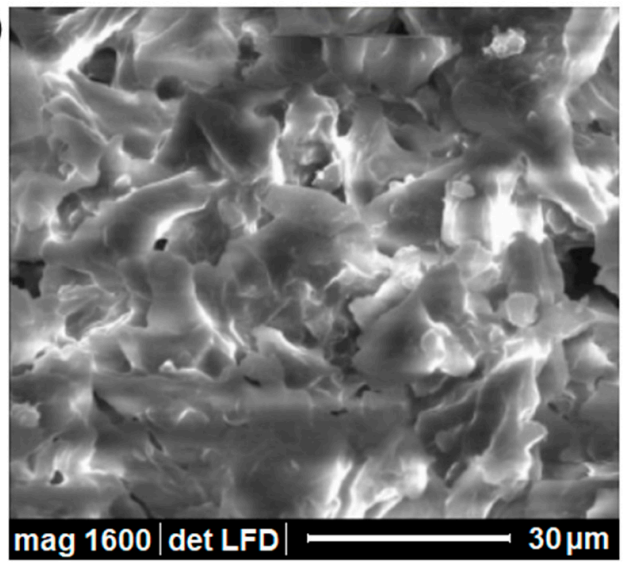

(c)

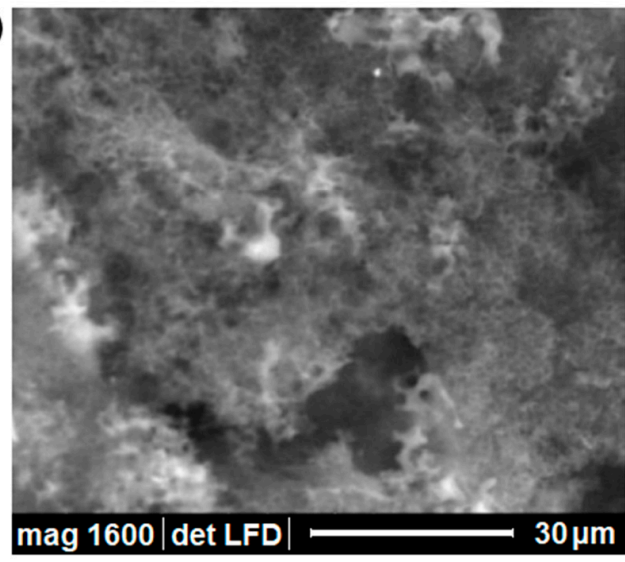

(b)

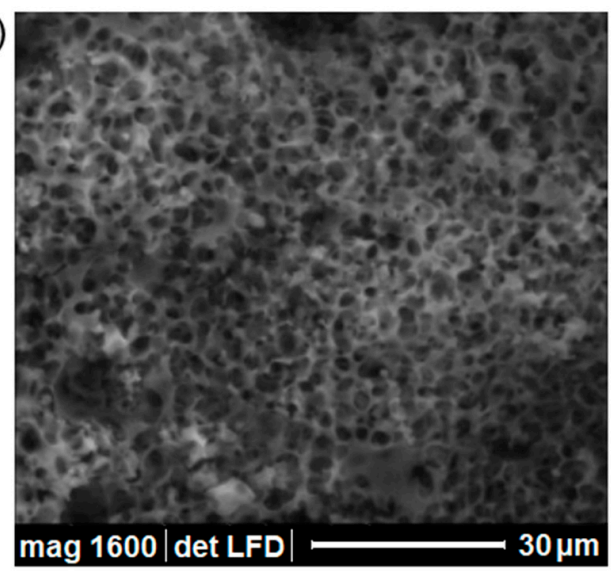

(d)

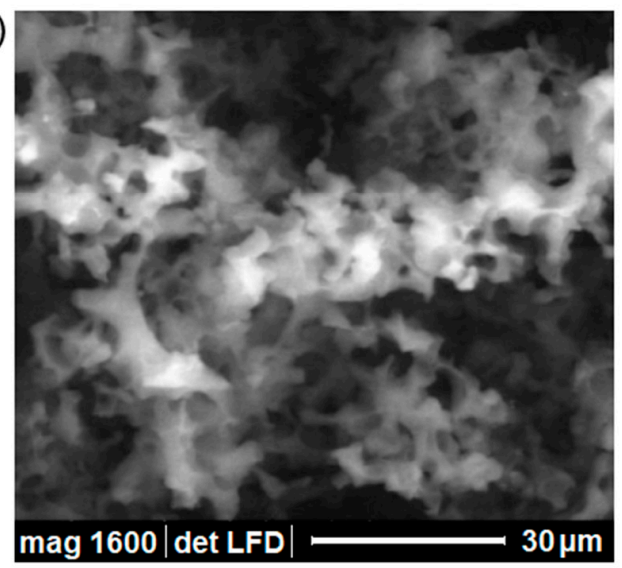

Figure 8. Environmental scanning electron micrographs $(1600 \times)$ of (a) the raw material A and the derived (b) AAC-5 (pyrolysis at $600{ }^{\circ} \mathrm{C}$, activator $\mathrm{KOH}$ ), (c) AAC-2 (pyrolysis at $800^{\circ} \mathrm{C}$, activator $\mathrm{KOH}$ ), and (d) AAC-3 (pyrolysis at $800{ }^{\circ} \mathrm{C}$, activator $\mathrm{NaHCO}_{3}$ ). Scale bar $30 \mu \mathrm{m}$.

The TEM images of some samples are reported in Figure S12. The non-uniformity of light transmittance confirms that all samples possess a diversity of pore structures randomly distributed, consistent with ESEM results. The observation that in AAC-5 only a few graphitic layers are visible at the edges of the porous structure, while in AAC-6 and AAC-7 they are more numerous and more extensive, indicates a graphitization and exfoliation level that depends on the temperature.

\subsection{General Considerations on Characterization Data and Correlations}

In this paper we would try to evidence possible correlations between the data obtained from different measurements which observe the same property but from different points of view.

It is noteworthy that, even if it was not possible establish a direct correlation, by considering the data relative to the samples with BET value higher than $1000 \mathrm{~m}^{2} / \mathrm{g}$, the set 
of $\mathrm{I}_{\mathrm{D} 1} / \mathrm{I}_{\mathrm{G} 1}, \mathrm{I}_{\mathrm{D} 2} / \mathrm{I}_{\mathrm{G} 2}$ and $\mathrm{I}_{\mathrm{G} 2} / \mathrm{I}_{\mathrm{G} 1}$ have quite similar values ranging between 2.2-2.9 (average value $2.7 \pm 0.5$ ), $1.4-2.1$ (average value $1.8 \pm 0.4$ ) and 2.0-2.8 (average value $2.4 \pm 0.4$ ), respectively (Table $S 4)$.

Some trends can be observed between the $\mathrm{I}_{\mathrm{D}} / \mathrm{I}_{\mathrm{G}}$ values from Raman spectra and the pores diameter for the samples which developed a value higher than $1000 \mathrm{~m}^{2} / \mathrm{g}$ (Figure S13a) and similarly by considering the samples with lower BET values, where we could suggest that the porosity has been only partially developed (Figure S13b). A trend can be seen also between the $I_{D} / I_{G}$ values and the specific surface area value for the same samples (Figure S14).

A good correlation can be achieved by considering BET values and the $V_{t}$, even if the data concerning the samples with lower BET values appear to be more scattered (Figure 9). The data concerning LP39 have not considered here, showing a completely different morphology and porosity in the ESEM images (Figure S11).

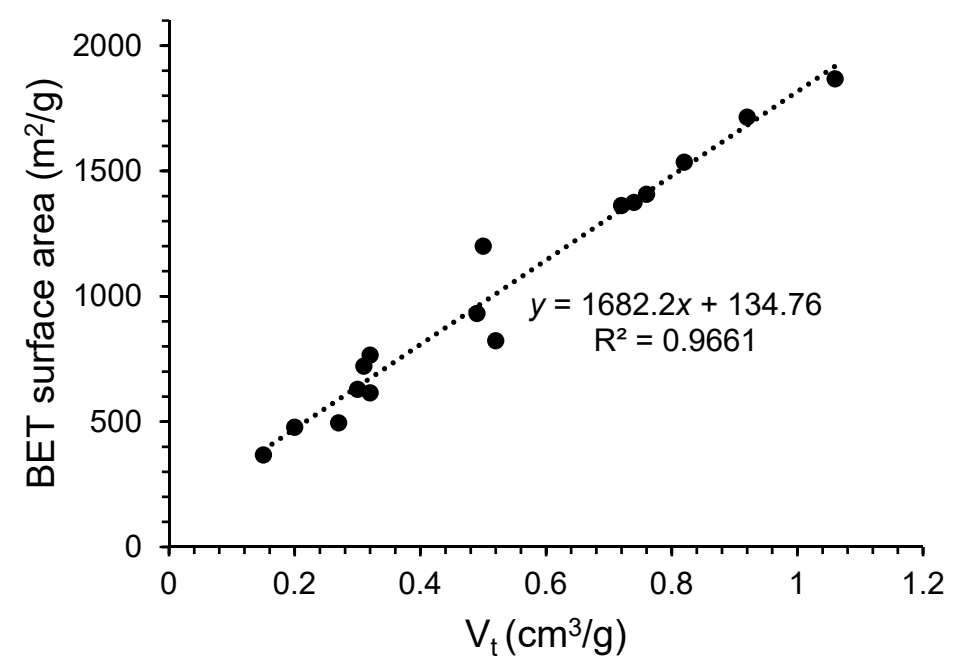

Figure 9. Correlation between specific surface area and total pore volume for samples with surface area higher than $1000 \mathrm{~m}^{2} / \mathrm{g}$.

Again, a good correlation can be obtained between the $\mathrm{I}_{\mathrm{D}} / \mathrm{I}_{\mathrm{G}}$ ratio derived from the Raman spectra and the $\mathrm{sp}^{2} /\left(\mathrm{sp}^{2}+\mathrm{sp}^{3}\right)$ values obtained by XPS data (Figure 10), considering only the samples which developed a specific surface area higher than $1000 \mathrm{~m}^{2} / \mathrm{g}$ (except LP39).

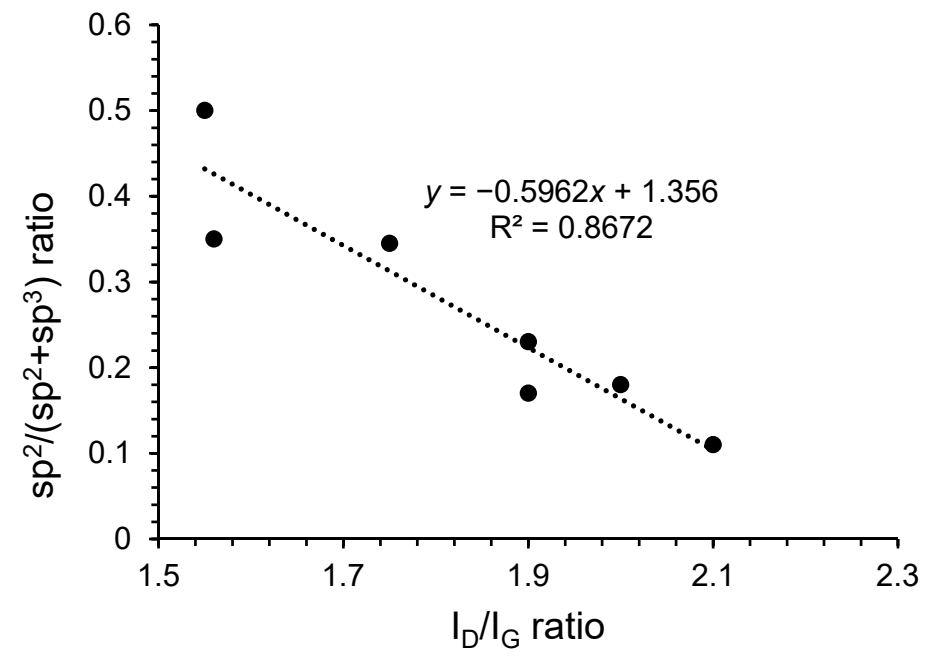

Figure 10. Correlation between Raman $I_{D} / I_{G}$ ratio and XPS $\mathrm{sp}^{2} /\left(\mathrm{sp}^{2}+\mathrm{sp}^{3}\right)$ data for samples with surface area higher than $1000 \mathrm{~m}^{2} / \mathrm{g}$. 


\section{Conclusions}

In conclusion, we observed that, for the series of activated carbons here reported, the experimental data can be correlated with the preparation method and that the results achieved from different measurement techniques can in principle be correlated with each other. Further and deeper studies will be necessary to better understand these correlations with the aim of previewing, for instance, an approximate specific surface area from Raman or XRD measurements. It was not possible to extend this approach to the numerous data in the literature, since not all the data and the necessary details are usually reported in the papers.

Research is ongoing to prepare other samples, starting from different biomasses and by using different activating agents such as $\mathrm{Na}_{2} \mathrm{CO}_{3}$ or $\mathrm{NaHCO}_{3}$, with the aim to explain more deeply, from the theoretical point of view, these empirical correlations, and to discover other relationships that will deepen understanding of the morphology of carbonaceous materials.

Supplementary Materials: The following are available online at https:/ / www.mdpi.com/article/10 $.3390 /$ pr9091637/s1, Figure S1: ESEM data of the starting SCGs; Figure S2: GC MS analysis of the EtOH mother liquors after washing spent coffee grounds from Arabica; Figure S3 (a): ${ }^{13 C}$ HPDEC NMR spectrum in the solid state of caffeine; Figure S3 (b): ${ }^{13 C}$ HPDEC NMR spectrum in the solid state of R and A samples; Table S1: ${ }^{13 C}$ MAS Chemical shifts; Figure S4: TG and DTG profiles of R and A under air; Table S2: TG and DTG data of samples A, R, A/KOH, and R/KOH 1/1 mixtures in the range $30-1000{ }^{\circ} \mathrm{C}$ under nitrogen; Figure S5 (a): GC MS analysis of the acetone solution of the residue after treatment at $380^{\circ} \mathrm{C}$ for $6 \mathrm{~h}$ under nitrogen of a 1:1 mixture A:KOH; Figure S5 (b): Environmental scanning electron microscopy (ESEM) images of the black powder recovered from treatment at $380^{\circ} \mathrm{C}$ for $6 \mathrm{~h}$ under nitrogen of a 1:1 mixture A:KOH; Figure S6: Raman spectra of the prepared activated carbons; Figure S7: XRD spectra; Figure S8: XPS spectra: (a) C 1s signal; (b) O 1s signal; (c) N 1s signal; Table S3: Parameters obtained from fitting two Gaussians as G and D bands to the Raman spectra of the ACs samples; Table S4: Parameters in ACs samples obtained from fitting four Gaussians G1, G2, D1 and D2 to the Raman spectra in the region 1000-1600 cm ${ }^{-1}$; Table S5. Parameters in ACs samples obtained from fitting four Gaussians $G^{*}, G^{\prime \prime}, D_{+} D^{\prime}$ and 2D' to the Raman spectra in the region $2300-3200 \mathrm{~cm}^{-1}$; Table S6. Elemental composition $(\% w / w)$ of the ACs from XPS data compared with elemental analysis and EDX data; Figure S9: Selected ${ }^{13 C}$ NMR spectra in the solid state of the prepared AC; Figure S10: Selected $\mathrm{N}_{2}$ absorption isotherm profiles together with pore size distribution; Figure S11. ESEM images of the activated carbons at different magnifications; Figure S12: TEM images of the samples AAC-5, AAC-6, and AAC-7, prepared by $\mathrm{KOH}$ activation at $600{ }^{\circ} \mathrm{C}, 700{ }^{\circ} \mathrm{C}$ and $800{ }^{\circ} \mathrm{C}$, respectively; Figure $\mathrm{S} 13$ (a): Raman $\mathrm{I}_{\mathrm{D}} / \mathrm{I}_{\mathrm{G}}$ ratio vs. pore diameter for samples with BET values higher than $1000 \mathrm{~m}^{2} / \mathrm{g}$; Figure $\mathrm{S} 13$ (b): Raman $\mathrm{I}_{\mathrm{D}} / \mathrm{I}_{\mathrm{G}}$ ratio vs. pore diameter for samples with BET values lower than $1000 \mathrm{~m}^{2} / \mathrm{g}$; Figure S14: Raman $\mathrm{I}_{\mathrm{D}} / \mathrm{I}_{\mathrm{G}}$ ratio vs. specific surface area for samples with BET values higher than $1000 \mathrm{~m}^{2} / \mathrm{g}$.

Author Contributions: Conceptualization, P.S., R.B., S.B. (Sara Bogialli), E.M., R.K. and A.P.d.C.R.; methodology, S.B. (Sadjia Benhabiles), E.R.; investigation, S.B. (Sadjia Benhabiles), E.R., A.T., F.V., A.G., F.Z., S.M.C., A.T., S.T. and A.F.; writing—original draft preparation, R.B.; writing-review and editing, P.S. and M.M.; All authors have read and agreed to the published version of the manuscript.

Funding: This research was funded by the Department of Industrial Engineering (DII), University of Padova, TWINNING-2017 research project "Supramolecular transition-metal architectures based on non-covalent interactions for selective molecular sorption and non-linear optics: Rational design and preparation".

Institutional Review Board Statement: Not applicable.

Informed Consent Statement: Not applicable.

Conflicts of Interest: The authors declare no conflict of interest. The funders had no role in the design of the study; in the collection, analyses, or interpretation of data; in the writing of the manuscript, or in the decision to publish the results. 


\section{References}

1. Galanakis, C. Handbook of Coffee Processing By-Products: Sustainable Applications, 1st ed.; Academic Press: London, UK, 2017; Chapters 3 and 9, In Particular.

2. Zabaniotou, A.; Kamaterou, P. Food waste valorisation advocating circular bioeconomy. A critical review of potentialities and perspectives of spent coffee grounds biorefinery. J. Clean. Prod. 2019, 211, 1553-1566. [CrossRef]

3. Campos-Vega, R.; Loarca-Pina, G.; Vergara-Castaneda, H.A.; Oomah, B.D. Spent coffee grounds: A review on current research and future prospects. Trends Food Sci. Technol. 2015, 45, 24-36. [CrossRef]

4. Karmee, S.K. A spent coffee grounds based biorefinery for the production of biofuels, biopolymers, antioxidants and biocomposites. Waste Manag. 2018, 72, 240-254. [CrossRef]

5. Osman, A.I.; Abdelkader, A.; Farrell, C.; Rooney, D.; Morgan, K. Reusing, recycling and up-cycling of biomass: A review of practical and kinetic modelling approaches. Fuel Process. Technol. 2019, 192, 179-202. [CrossRef]

6. Atabani, A.E.; Al-Muhtaseb, A.H.; Kumar, G.; Saratale, G.D.; Aslam, M.; Khan, H.A.; Said, Z.; Mahmoud, E. Valorization of spent coffee grounds into biofuels and value-added products: Pathway towards integrated bio-refinery. Fuel 2019, $254,115640$. [CrossRef]

7. Massaya, J.; Pereira, A.P.; Mills-Lamptey, B.; Benjamin, J.; Chuck, C.J. Conceptualization of a spent coffee grounds biorefinery: A review of existing valorisation approaches. Food Bioprod. Process. 2019, 118, 149-166. [CrossRef]

8. Mussatto, S.I.; Machado, E.M.S.; Martins, S.; Teixeira, J.A. Production, composition, and application of coffee and its industrial residues. Food Bioprocess Technol. 2011, 4, 661-672. [CrossRef]

9. Girotto, F.; Pivato, A.; Cossu, R.; Nkeng, G.E.; Lavagnolo, M.C. The broad spectrum of possibilities for spent coffee grounds valorisation. J. Mater. Cycles Waste Manag. 2018, 20, 695-701. [CrossRef]

10. Stylianou, M.; Agapiou, A.; Omirou, M.; Vyrides, I.; Ioannides, I.M.; Maratheftis, G.; Fasoula, D. Converting environmental risks to benefits by using spent coffee grounds (SCG) as a valuable resource. Environ. Sci. Pollut. Res. 2018, 25, 35776-35790. [CrossRef]

11. Peshev, D.; Mitev, D.; Peeva, L.; Peev, G. Valorization of spent coffee grounds-A new approach. Sep. Purif. Technol. 2018, 192, 271-277. [CrossRef]

12. Nguyen, Q.A.; Cho, E.J.; Lee, D.S.; Bae, H.J. Development of an advanced integrative process to create valuable biosugars including manno-oligosaccharides and mannose from spent coffee grounds. Bioresour. Technol. 2019, 272, 209-216. [CrossRef]

13. Tongcumpou, C.; Usapein, P.; Tuntiwiwattanapun, N. Complete utilization of wet spent coffee grounds waste as a novel feedstock for antioxidant, biodiesel, and bio-char production. Ind. Crop. Prod. 2019, 138, 111484. [CrossRef]

14. Dattatraya Saratale, G.; Bhosale, R.; Shobana, S.; Banu, J.R.; Pugazhendhi, A.; Mahmoud, E.; Sirohi, R.; Bhatia, S.K.; Atabani, A.E.; Mulone, V.; et al. A review on valorization of spent coffee grounds (SCG) towards biopolymers and biocatalysts production. Bioresour. Technol. 2020, 314, 123800. [CrossRef]

15. Tan, M.Y.; Kuan, H.T.N.; Lee, M.C. Characterization of alkaline treatment and fiber content on the physical, thermal and mechanical properties of ground coffee waste/oxobiodegradable HDPE biocomposites. Int. J. Polym. Sci. 2017, $2017,6258151$. [CrossRef]

16. Yoo, J.; Chang, S.J.; Wi, S.; Kim, S. Spent coffee grounds as supporting materials to produce biocomposite PCM with natural waxes. Chemosphere 2019, 235, 626-635. [CrossRef] [PubMed]

17. Chun, Y.; Ko, Y.G.; Do, T.; Jung, Y.; Kim, S.W.; Choi, U.S. Spent coffee grounds: Massively supplied carbohydrate polymer applicable to electrorheology. Colloids Surfaces A Physicochem. Eng. Asp. 2019, 562, 392-401. [CrossRef]

18. Cruz, R.; Mendes, E.; Torrinha, A.; Morais, S.; Pereira, J.A.; Baptista, P.; Casal, S. Revalorization of spent coffee residues by a direct agronomic approach. Food Res. Int. 2015, 71, 190-196. [CrossRef]

19. Elbl, J.; Plosek, L.; Kintl, A.; Prichystalova, J.; Zahora, J.; Friedel, J.K. The effect of increased doses of compost on leaching of mineral nitrogen from arable land. Pol. J. Environ. Stud. 2014, 23, 697-703.

20. Sikka, S.S.; Chawla, I.S. Effect of feeding spent coffee grounds on the feedlot performance of carcass quality of fattening pigs. Agric. Wastes 1986, 18, 305-308. [CrossRef]

21. Mendoza Martinez, C.L.; Alves Rocha, E.P.; Oliveira Carneiro, A.C.; Borges Gomes, F.J.; Ribas Batalha, L.A.; Vakkilainen, E.; Cardoso, M. Characterization of residual biomasses from the coffee production chain and assessment the potential for energy purposes. Biomass Bioenerg. 2019, 120, 68-76. [CrossRef]

22. Nguyen, H.C.; Nguyen, M.L.; Wang, F.M.; Juan, H.Y.; Su, C.H. Biodiesel production by direct transesterification of wet spent coffee grounds using switchable solvent as a catalyst and solvent. Bioresour. Technol. 2020, 296, 122334. [CrossRef]

23. Dohlert, P.; Weidauer, M.; Enthaler, S. Spent coffee ground as source for hydrocarbon fuels. J. Energy Chem. 2016, 25, 146-152. [CrossRef]

24. Fischer, A.; Du, S.; Valla, J.A.; Bollas, G.M. The effect of temperature, heating rate and ZSM-5 catalyst on the product selectivity of the fast pyrolysis of spent coffee grounds. RCS Adv. 2015, 5, 29252-29261. [CrossRef]

25. Tehrani, N.F.; Aznar, J.S.; Kiros, Y. Coffee extract residue for production of ethanol and activated carbons. J. Clean. Prod. 2015, 91, 64-70. [CrossRef]

26. Vardon, D.R.; Moser, B.R.; Zheng, W.; Witkin, K.; Evangelista, R.L.; Strathmann, T.J.; Rajagopalan, K.; Sharma, B.K. Complete utilization of spent coffee grounds to produce biodiesel, bio-oil and biochar. ACS Sustain. Chem. Eng. 2013, 1, 1286-1294. [CrossRef] 
27. Primaz, C.T.; Schena, T.; Lazzari, E.; Caramao, E.B.; Jaques, R.A. Influence of the temperature in the yield and composition of the bio-oil from the pyrolysis of spent coffee grounds: Characterization by comprehensive two dimensional gas chromatography. Fuel 2018, 232, 572-580. [CrossRef]

28. Cay, H.; Duman, G.; Yanik, J. Two-step gasification of biochar for hydrogen-rich gas production: Effect of the biochar type and catalyst. Energy Fuels 2019, 33, 7398-7405. [CrossRef]

29. Jutakridsada, P.; Prajaksud, C.; Kuboonya-Aruk, L.; Theerakulpisut, S.; Kamwilaisak, K. Adsorption characteristics of activated carbon prepared from spent ground coffee. Clean Technol. Environ. Policy 2016, 18, 639-645. [CrossRef]

30. Alcaraz, L.; Escudero, M.E.; Alguacil, F.J.; Llorente, I.; Urbieta, A.; Fernandez, P.; Lopez, F.A. Dysprosium removal from water using active carbons obtained from spent coffee ground. Nanomaterials 2019, 9, 1372. [CrossRef] [PubMed]

31. Babu, N.A.; Reddy, D.S.; Kumar, G.S.; Ravindhranath, K.; Mohan, G.V.K. Removal of lead and fluoride from contaminated water using exhausted coffee grounds based bio-sorbent. J. Environ. Manag. 2018, 218, 602-612. [CrossRef]

32. Fonseca Alves, A.C.; Antero, R.V.P.; de Oliveira, S.B.; Ojala, S.A.; Scalize, P.S. Activated carbon produced from waste coffee grounds for an effective removal of bisphenol-A in aqueous medium. Environ. Sci. Pollut. Res. 2019, 26, 24850-24862. [CrossRef] [PubMed]

33. Wang, C.F.; Wu, C.L.; Kuo, S.W.; Hung, W.S.; Lee, K.J.; Tsai, H.C.; Chang, C.J.; Lai, J.Y. Preparation of efficient photothermal materials from waste coffee grounds for solar evaporation and water purification. Sci. Rep. 2020, 10, 12769. [CrossRef] [PubMed]

34. Huang, S.; Liang, C. Evaluation of the engineering properties of powdered activated carbon amendments in porous asphalt pavement. Processes 2021, 9, 582. [CrossRef]

35. Suganya, S.; Kumar, P.S. Influence of ultrasonic waves on preparation of active carbon from coffee waste for the reclamation of effluents containing Cr(VI) ions. J. Ind. Eng. Chem. 2018, 60, 418-430. [CrossRef]

36. Rovani, S.; Censi, M.T.; Pedrotti, S.L., Jr.; Lima, E.C.; Cataluna, R.; Fernandes, A.N. Development of a new adsorbent from agro-industrial waste and its potential use in endocrine disruptor compound removal. J. Hazard. Mater. 2014, 271, 311-320. [CrossRef]

37. Nowicki, P.; Skibiszewska, P.; Pietrzak, R. Hydrogen sulphide removal on carbonaceous adsorbents prepared from coffee industry waste materials. Chem. Eng. J. 2014, 248, 208-215. [CrossRef]

38. Querejeta, N.; Gil, M.V.; Rubiera, F.; Pevida, C. Sustainable coffee-based $\mathrm{CO}_{2}$ adsorbents: Toward a greener production via hydrothermal carbonization. Greenh. Gases Sci. Technol. 2018, 8, 309-323. [CrossRef]

39. Travis, W.; Gadipelli, S.; Guo, Z. Superior $\mathrm{CO}_{2}$ adsorption from waste coffee ground derived carbons. RCS Adv. 2015, 5, 29558-29562. [CrossRef]

40. Mohamed, M.G.; Ahmed, M.M.M.; Du, W.T.; Kuo, S.W. Meso/Microporous carbon from conjugated hyper-crosslinked polymers based on tetraphenylethene for high-performance $\mathrm{CO}_{2}$ capture and supercapacitor. Molecules 2021, 16, 738. [CrossRef]

41. Samy, M.M.; Mohamed, M.G.; Kuo, S.W. Directly synthesized nitrogen and oxygen doped microporous carbons derived from a bio-derived polybenzoxazine exhibiting high-performance supercapacitance and $\mathrm{CO}_{2}$ uptake. Eur. Polym. J. 2020, 138, 109954 [CrossRef]

42. Kemp, K.C.; Baek, S.B.; Lee, W.G.; Meyyappan, M.; Kim, K.S. Activated carbon derived from waste coffee grounds for stable methane storage. Nanotechnology 2015, 26, 385602-385609. [CrossRef] [PubMed]

43. Akasaka, H.; Takahata, T.; Toda, I.; Ono, H.; Ohshio, S.; Himeno, S.; Kokubu, T.; Saitoh, H. Hydrogen storage ability of porous carbon material fabricated from coffee bean wastes. Int. J. Hydrogen Energy 2011, 36, 580-585. [CrossRef]

44. Um, J.H.; Kim, Y.; Ahn, C.Y.; Kim, J.; Sung, Y.E.; Cho, Y.H.; Kim, S.S.; Yoon, W.S. Biomass waste, coffee grounds-derived carbon for lithium storage. J. Electrochem. Sci. Technol. 2018, 9, 163-168. [CrossRef]

45. Oh, W.D.; Lisak, G.; Webster, R.D.; Liang, Y.N.; Veksha, A.; Giannis, A.; Moo, J.G.S.; Lim, J.W.; Lim, T.T. Insights into the thermolytic transformation of lignocellulosic biomass waste to redox-active carbocatalyst: Durability of surface active sites. Appl. Catal. B Environ. 2018, 233, 120-129. [CrossRef]

46. Goncalves, M.; Guerreiro, M.C.; Alves de Oliveira, L.C.; Soares de Castro, C. A friendly environmental material: Iron oxide dispersed over activated carbon from coffee husk for organic pollutants removal. J. Environ. Manag. 2013, 127, 206-211. [CrossRef]

47. Hung, Y.H.; Liu, T.Y.; Chen, H.Y. Renewable coffee waste-derived porous carbons as anode materials for high-performance sustainable microbial fuel cells. ACS Sustain. Chem. Eng. 2019, 7, 16991-16999. [CrossRef]

48. Lee, M.E.; Kwak, H.W.; Jin, H.J.; Yun, Y.S. Waste beverage coffee-induced hard carbon granules for sodium-ion batteries. ACS Sustain. Chem. Eng. 2019, 7, 12734-12740. [CrossRef]

49. Zhao, P.; Aboonasr Shiraz, M.H.; Zhu, H.; Liu, Y.; Tao, L.; Liu, J. Hierarchically porous carbon from waste coffee grounds for high-performance Li-Se batteries. Electrochim. Acta 2019, 325, 134931-134938. [CrossRef]

50. Choi, J.; Zequine, C.; Bhoyate, S.; Lin, W.; Li, X.; Kahol, P.; Gupta, R. Waste coffee management: Deriving high-performance supercapacitors using nitrogen-doped coffee-derived carbon. C J. Carbon Res. 2019, 5, 44. [CrossRef]

51. Frohlich, A.C.; dos Reis, G.S.; Pavan, F.A.; Lima, E.C.; Foletto, E.L.; Dotto, G.L. Improvement of activated carbon characteristics by sonication and its application for pharmaceutical contaminant adsorption. Environ. Sci. Pollut. Res. 2018, 25, 24713-24725. [CrossRef]

52. Kim, Y.; Lee, J.; Yi, H.; Tsang, Y.F.; Kwon, E.E. Investigation into role of $\mathrm{CO}_{2}$ in two-stage pyrolysis of spent coffee grounds. Bioresour. Technol. 2019, 272, 48-53. [CrossRef] 
53. Laksaci, H.; Khelifi, A.; Trari, M.; Addoun, A. Synthesis and characterization of microporous activated carbon from coffee grounds using potassium hydroxide. J. Clean. Prod. 2017, 147, 254-262. [CrossRef]

54. Laksaci, H.; Khelifi, A.; Belhamdi, B.; Trari, M. Valorization of coffee grounds into activated carbon using physic-chemical activation by $\mathrm{KOH} / \mathrm{CO}_{2}$. J. Environ. Chem. Eng. 2017, 5, 5061-5066. [CrossRef]

55. Rodriguez-Reinoso, F; Molina-Sabio, M.; Gonzalez, M.T. The use of steam and $\mathrm{CO}_{2}$ as activating agents in the preparation of activated carbons. Carbon 1995, 33, 15-23. [CrossRef]

56. Chiu, Y.H.; Lin, L.Y. Effect of activating agents for producing activated carbon using a facile one-step synthesis with waste coffee grounds for symmetric supercapacitors. J. Taiwan Inst. Chem. Eng. 2019, 101, 177-185. [CrossRef]

57. Wang, C.H.; Wen, W.C.; Hsu, H.C.; Yao, B.Y. High-capacitance KOH-activated nitrogen-containing porous carbon material from waste coffee grounds in supercapacitors. Adv. Power Technol. 2016, 27, 1387-1395. [CrossRef]

58. Pujol, D.; Liu, C.; Gominho, J.; Olivella, M.A.; Fiol, N.; Villaescusa, I.; Pereira, H. The chemical composition of exhausted coffee waste. Ind. Crop. Prod. 2013, 50, 423-429. [CrossRef]

59. Wilson, L.; Yang, W.; Blasiak, W.; John, G.R.; Mhilu, C.F. Thermal characterization of tropical biomass feedstocks. Energy Conv. Manag. 2011, 52, 191-198. [CrossRef]

60. Pawlicka, A.; Doczekalska, B. Determination of surface oxygen functional groups of active carbons according to Bohem's titration method. For. Wood Technol. 2013, 84, 11-14.

61. Kumar, A.; Prasad, B.; Mishra, I.M. Adsorptive removal of acrylonitrile by commercial grade activated carbon: Kinetics, equilibrium and thermodynamics. J. Hazard. Mater. 2007, 152, 589-600. [CrossRef]

62. Ballesteros, L.F.; Teixeira, J.A.; Mussatto, S.I. Chemical, functional and structural properties of spent coffee grounds and coffee silverskin. Food Bioprocess Technol. 2014, 7, 3493-3503. [CrossRef]

63. Sharma, R.K.; Hajaligol, M.R.; Martoglio Smith, P.A.; Wooten, J.B.; Baliga, V. Characterization of char pyrolysis of chlorogenic acid. Energy Fuels 2000, 14, 1083-1093. [CrossRef]

64. Wang, N.; Lim, L.T. Fourier transform infrared and physicochemical analyses of roasted coffee. J. Agric. Food Chem. 2012, 60, 5446-5453. [CrossRef]

65. Li, X.; Strezov, V.; Kan, T. Energy recovery potential analysis of spent coffee grounds pyrolysis products. J. Anal. Appl. Pyrolysis 2014, 110, 79-87. [CrossRef]

66. Skreiberg, A.; Skreiberg, O.; Sandquist, J.; Sorum, L. TGA and macro-TGA characterization of biomass fuels and fuel mixtures. Fuel 2011, 90, 2182-2197. [CrossRef]

67. Fermoso, J.; Masek, O. Thermochemical decomposition of coffee ground residues by TG-MS: A kinetic study. J. Anal. Appl. Pyrolysis 2018, 130, 358-367. [CrossRef]

68. Chia, C.H.; Gong, B.; Joseph, S.D.; Marjo, C.E.; Munroe, P.; Rich, A.M. Imaging of mineral-enriched biochar by FTIR, Raman and SEM-EDX. Vib. Spectrosc. 2012, 62, 248-257. [CrossRef]

69. Centrone, A.; Brambilla, L.; Renouard, T.; Gherghel, L.; Mathis, C.; Mullen, K.; Zerbi, G. Structure of new carbonaceous materials: The role of vibrational spectroscopy. Carbon 2005, 43, 1593-1609. [CrossRef]

70. Zhuo, Y.; Lemaignen, L.; Chatzakis, I.N.; Reed, G.P.; Dugwell, D.R.; Kandiyoti, R. An attempt to correlate conversion in pyrolysis and gasification with FT-IR spectra of coals. Energy Fuels 2000, 14, 1049-1058. [CrossRef]

71. Shimodaira, N.; Masui, A. Raman spectroscopic investigations of activated carbon materials. J. Appl. Phys. 2002, 92, 902-909. [CrossRef]

72. Ferrari, A.C.; Robertson, J. Interpretation of Raman spectra of disordered and amorphous carbon. Phys. Rev. B 2000, 61, 14095-14107. [CrossRef]

73. Ferrari, A.C. Raman spectroscopy of graphene and graphite: Disorder, electron-phonon coupling, doping and nonadiabatic effects. Solid State Commun. 2007, 143, 47. [CrossRef]

74. Kaniyoor, A.; Ramaprabhu, S. A Raman spectroscopic investigation of graphite oxide derived graphene. AIP Adv. 2012, 2, 032183. [CrossRef]

75. Malard, L.M.; Pimenta, M.A.; Dresselhaus, G.; Dresselhaus, M.S. Raman spectroscopy in graphene. Phys. Rep. 2008, 473, 51-87. [CrossRef]

76. Pimenta, M.A.; Dresselhaus, G.; Dresselhaus, M.S.; Cancado, L.G.; Jorio, A.; Saito, R. Studying disorder in graphite-based systems by Raman spectroscopy. Phys. Chem. Chem. Phys. 2007, 9, 1276-1291. [CrossRef] [PubMed]

77. Tan, P.H.; Deng, Y.M.; Zhao, Q. Temperature-dependent Raman spectra and anomalous Raman phenomenon of highly oriented pyrolytic graphite. Phys. Rev. 1998, 58, 5435-5439. [CrossRef]

78. Morgan, D.J. Comments on the XPS analysis of carbon materials. J. Carbon Res. 2021, 7, 51. [CrossRef]

79. Lesiak, B.; Kover, L.; Toth, J.; Zemek, J.; Jiricek, P.; Kromba, A.; Rangam, N. C sp ${ }^{2} / \mathrm{sp}^{3}$ hybridisations in carbon materials-XPS and (X)AES study. Appl. Surf. Sci. 2018, 452, 223-231. [CrossRef]

80. Li, X.; Kang, Y.; Haghighi, M. Investigation of pore size distributions of coals with different structures by nuclear magnetic resonance (NMR) and mercury intrusion porosimetry. Measurement 2018, 116, 122-128. [CrossRef]

81. McBeath, A.V.; Smernik, R.J.; Krull, E.S.; Lehmann, J. The influence of feedstock and production temperature on biochar carbon chemistry: A solid-state 13C NMR study. Biomass Bioenerg. 2014, 60, 121-129. [CrossRef]

82. Chen, L.S.; Wang, L.I.; Pan, T.Y.; Zhang, Y.Y.; Zhang, D.X. Calibration of solid state NMR carbon structural parameters and application in coal structure analysis. J. Fuel Chem. Technol. 2017, 45, 1153-1163. [CrossRef] 
83. Celzard, A.; Mareche, J.F.; Payot, F.; Furdin, G. Electrical conductivity of carbonaceous powders. Carbon 2002, 40, 2801-2815. [CrossRef]

84. Sanchez-Gonzalez, J.; Macias-Garcia, A.; Alexandre-Franco, M.F.; Gomez-Serrano, V. Electrical conductivity of carbon black under compressin. Carbon 2005, 43, 741-747. [CrossRef]

85. Vargas, A.M.M.; Cazetta, A.L.; Garcia, C.A.; Moraes, J.C.G.; Nogami, E.M.; Lenzi, E.; Costa, W.F.; Almeida, V.C. Preparation and characterization of activated carbon from a new raw lignocellulosic material: Flamboyant (Delonix regia) pods. J. Environ. Manag. 2011, 92, 178-184. [CrossRef]

86. Fuente, E.; Menendez, J.A.; Suarez, D.; Montes-Moran, M.A. Basic surface oxides on carbon materials: A global view. Langmuir 2003, 19, 3505-3511. [CrossRef]

87. Schonner, J.; Buchheim, J.R.; Scholz, P.; Adelhelm, P. Boehm titration revisited (part I): Practical aspects for achieving a high precision in quantifyng oxygen-containing surface groups on carbon materials. C J. Carbon Res. 2018, 4, 21. [CrossRef]

88. Takahata, T.; Toda, I.; Ono, H.; Ohshio, S.; Akasaka, H.; Himeno, S.; Kokubu, T.; Saitoh, H. Detailed structural analyses of KOH activated carbon from waste coffee beans. Jpn. J. Appl. Phys. 2009, 48, 117001. [CrossRef]

89. Rodriguez Correa, C.; Kruse, A. Biobased functional carbon materials: Production, characterization, and applications-A review. Materials 2018, 11, 1568. [CrossRef]

90. Yun, Y.S.; Park, M.H.; Hong, S.J.; Lee, M.E.; Park, Y.W.; Jin, H.J. Hierarchically porous carbon nanosheets from waste coffee grounds for supercapacitors. ACS Appl. Mater. Interfaces 2015, 7, 3684-3690. [CrossRef]

91. Mohamed, M.G.; Atajde, E.C., Jr.; Matsagar, B.M.; Na, J.; Yamauchi, Y.; Wu, K.C.W.; Kuo, S.W. Construction hierarchically mesoporous/microporous materials based on block copolymer and covalent organic framework. J. Taiwan Inst. Chem. Eng. 2020, 112, 180-192. [CrossRef]

92. Qian, M.; Xuan, X.Y.; Pan, L.K.; Gong, S.Q. Porous carbon electrodes from activated wastes coffee grounds for capacitive deionization. Ionics 2019, 25, 3443-3452. [CrossRef]

93. Ramon-Goncalves, M.; Alcarez, L.; Perez-Ferreras, S.; Leon-Gonzalez, M.E.; Rosales-Conrado, N.; Lopez, F.A. Extraction of polyphenols and synthesis of new activated carbon from spent coffee grounds. Sci. Rep. 2019, 9, 17706. [CrossRef] 